Prepared in cooperation with the Missouri Department of Natural Resources

\title{
Quality of Surface Water in Missouri, Water Year 2015
}

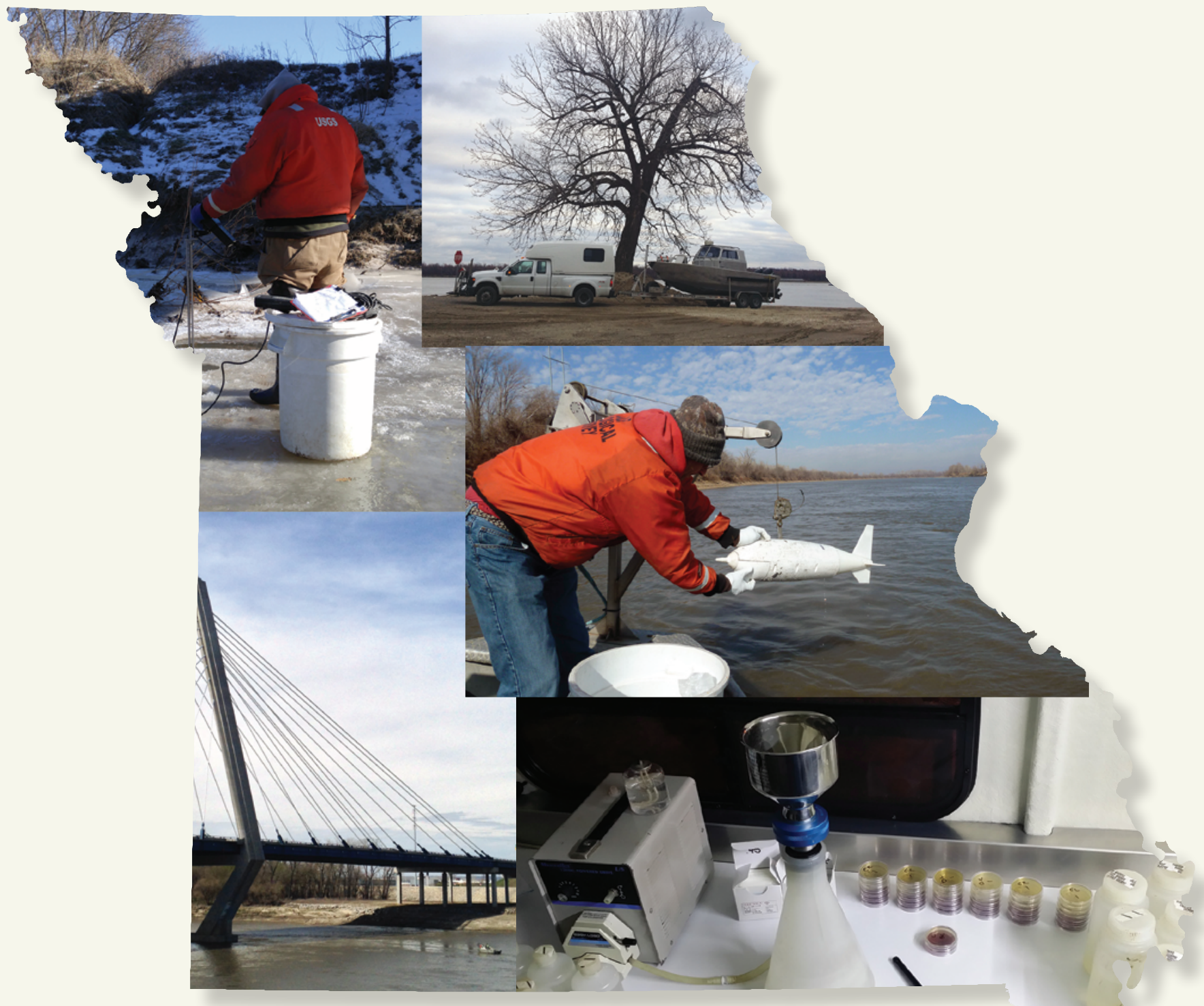

Data Series 1023

U.S. Department of the Interior

U.S. Geological Survey 


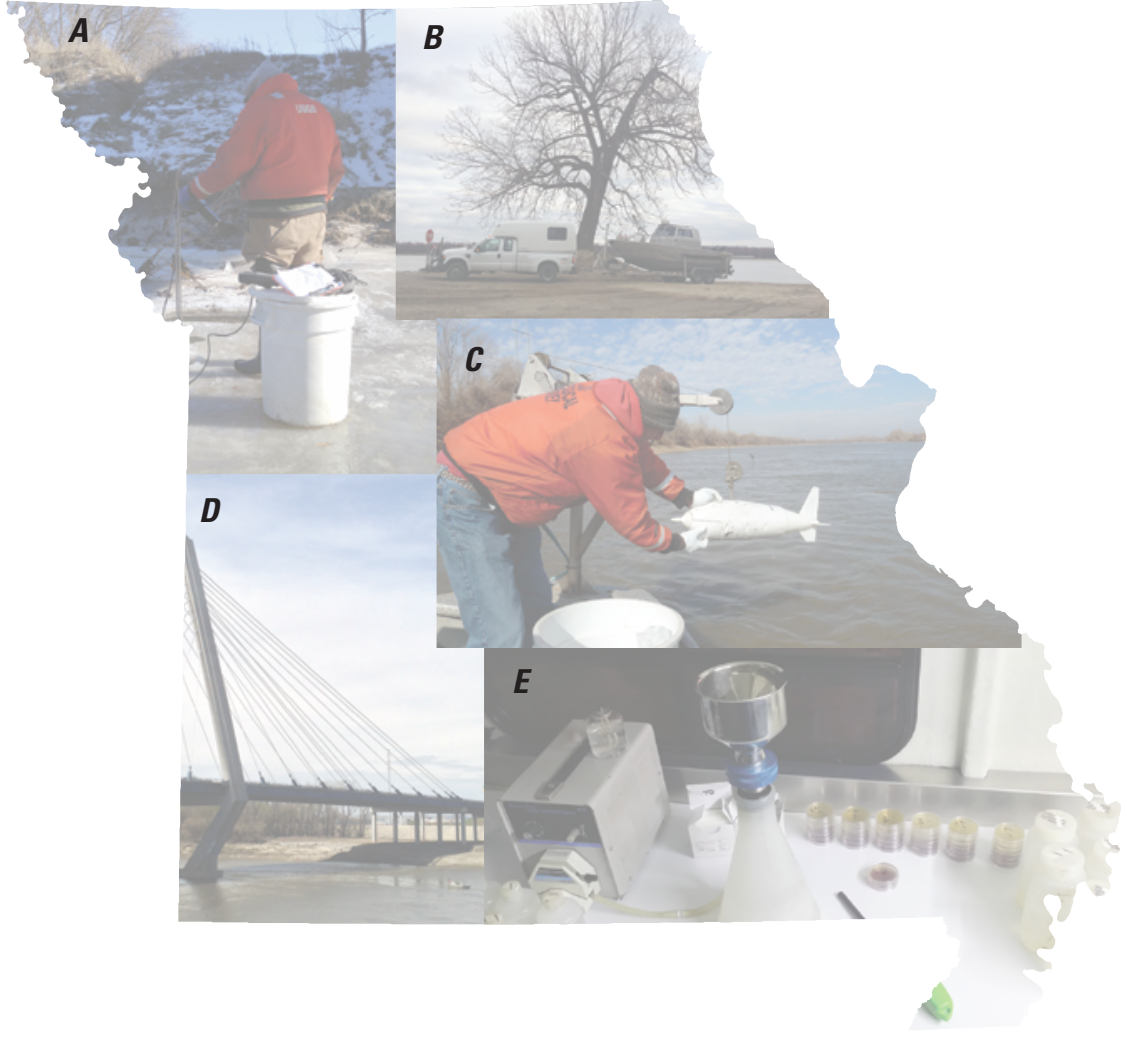

Cover illustration: $\quad \boldsymbol{A}$. Hydrologic technician making a discharge measurement on an ice-covered northern Missouri stream. B. U.S. Geological Survey mobile water-quality laboratory and sample collection boat. C. Hydrologic technician collecting surface water-quality sample at a Missouri River sampling station. D. U.S. Geological Survey work skiff traveling under the Christopher S. Bond bridge over the Missouri River in Kansas City, Missouri. E. Waterfiltration apparatus in mobile laboratory for processing surface-water quality samples for bacteria analyses.

(Photographs taken by U.S. Geological Survey personnel). 


\section{Quality of Surface Water in Missouri, Water Year 2015}

By Miya N. Barr and David C. Heimann

Prepared in cooperation with the Missouri Department of Natural Resources

Data Series 1023

U.S. Department of the Interior

U.S. Geological Survey 


\title{
U.S. Department of the Interior SALLY JEWELL, Secretary
}

\section{U.S. Geological Survey Suzette M. Kimball, Director}

\author{
U.S. Geological Survey, Reston, Virginia: 2016
}

For more information on the USGS - the Federal source for science about the Earth, its natural and living resources, natural hazards, and the environment—visit http://www.usgs.gov or call 1-888-ASK-USGS.

For an overview of USGS information products, including maps, imagery, and publications, visit http://www.usgs.gov/store.usgs.gov/.

Any use of trade, firm, or product names is for descriptive purposes only and does not imply endorsement by the U.S. Government.

Although this information product, for the most part, is in the public domain, it also may contain copyrighted materials as noted in the text. Permission to reproduce copyrighted items must be secured from the copyright owner.

Suggested citation:

Barr, M.N., and Heimann, D.C., 2016, Quality of surface water in Missouri, water year 2015: U.S. Geological Survey Data Series 1023, 22 p., http://dx.doi.org/10.3133/ds1023.

ISSN 2327-638X (online) 


\section{Contents}

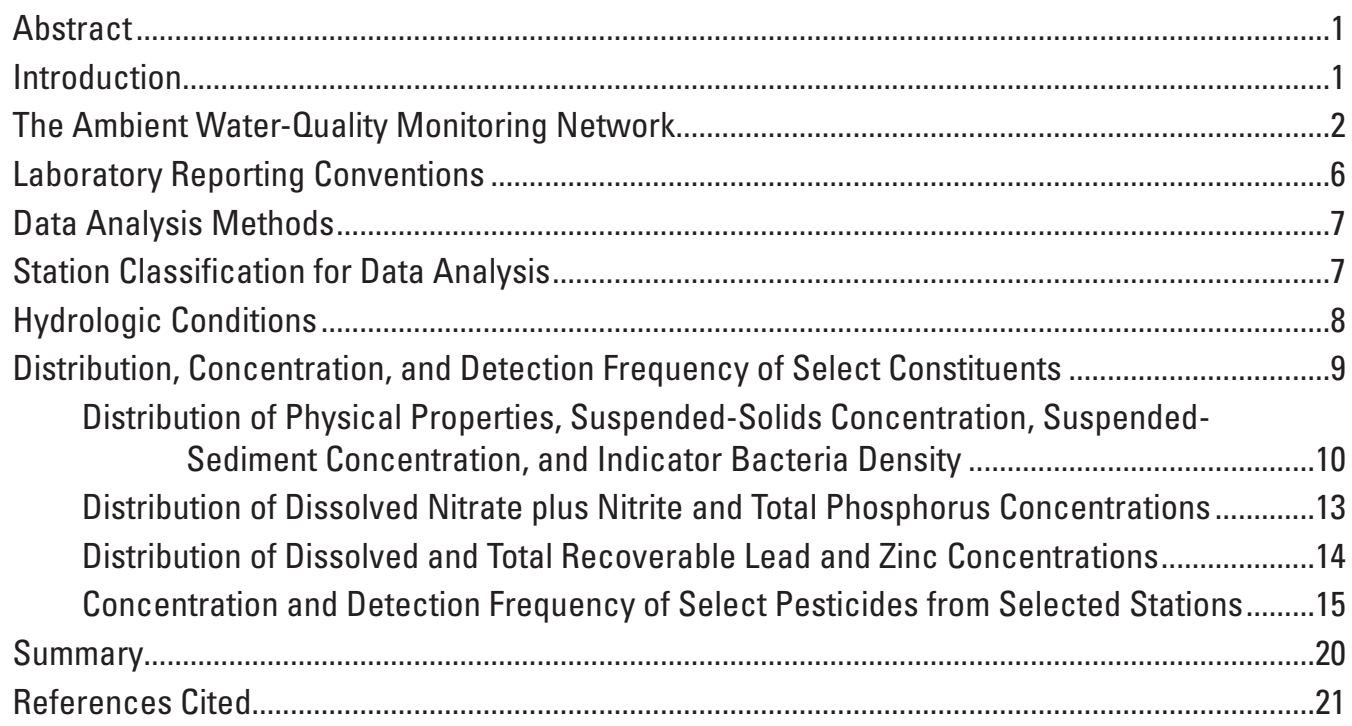

\section{Figures}

1. Map showing location, classes, types, and land-use indicators of selected stations and physiographic regions of Missouri, water year 2015.................................................

2. Map showing primary land use in Missouri..................................................................

3. Map showing location of selected streamflow-gaging stations used for summary of hydrologic conditions within Missouri, water year 2015...

4. Graphs showing monthly mean streamflow for water year 2015 and long-term mean monthly streamflow at six representative streamgages, in Missouri......

5. Graphs showing distribution of physical properties, suspended-solids concentrations, and suspended-sediment concentrations, in samples from 71 stations in Missouri, water year 2015.

6. Graphs showing distribution of indicator bacteria densities in samples from 71 stations in Missouri, water year 2015

7. Graphs showing distribution of dissolved nitrate plus nitrite as nitrogen and total phosphorus concentrations in samples from 71 stations in Missouri, water year 2015

8. Graphs showing distribution of dissolved and total recoverable lead and zinc concentrations from 71 stations in Missouri, water year 2015.

9. Graphs showing detection of select pesticides from selected stations in Missouri, water year 2015. 


\section{Tables}

1. U.S. Geological Survey station number, name, contributing drainage area, sampling frequency, and station class of 71 selected stations in Missouri, water year 2015 .

2. U.S. Geological Survey station classes and number of stations in each class, Missouri water year 2015 ...

3. Peak streamflow for water year 2015 and periods of record for selected streamgages, in Missouri

4. Seven-day low flow for water year 2015, period of record 7-day low flow, minimum daily mean streamflow for water year 2015 , and period of record minimum daily mean streamflow for selected streamgages in Missouri.....

\section{Conversion Factors}

U.S. customary units to International System of Units

\begin{tabular}{|c|c|c|}
\hline Multiply & By & To obtain \\
\hline \multicolumn{3}{|c|}{ Length } \\
\hline inch (in.) & 2.54 & centimeter $(\mathrm{cm})$ \\
\hline mile (mi) & 1.609 & kilometer (km) \\
\hline \multicolumn{3}{|c|}{ Area } \\
\hline \multirow[t]{2}{*}{ square mile $\left(\mathrm{mi}^{2}\right)$} & 2.590 & square kilometer $\left(\mathrm{km}^{2}\right)$ \\
\hline & Flow rate & \\
\hline cubic foot per second $\left(\mathrm{ft}^{3} / \mathrm{s}\right)$ & 0.02832 & cubic meter per second $\left(\mathrm{m}^{3} / \mathrm{s}\right)$ \\
\hline
\end{tabular}

\section{Supplimental Information}

Temperature in degrees Celsius $\left({ }^{\circ} \mathrm{C}\right)$ may be converted to degrees Fahrenheit $\left({ }^{\circ} \mathrm{F}\right)$ as follows: ${ }^{\circ} \mathrm{F}=\left(1.8 \mathrm{x}^{\circ} \mathrm{C}\right)+32$.

Specific conductance is given in microsiemens per centimeter at 25 degrees Celsius $(\mu \mathrm{S} / \mathrm{cm}$ at $\left.25^{\circ} \mathrm{C}\right)$.

Density of bacteria is given in colonies per 100 milliliters $(\mathrm{col} / 100 \mathrm{~mL}$ ) of water.

Concentrations of chemical constituents in water are given either in milligrams per liter (mg/L) or micrograms per liter $(\mu \mathrm{g} / \mathrm{L})$.

Water year in U.S. Geological Survey reports is the 12-month period October 1 through September 30 . The water year is designated by the calendar year in which it ends and which includes 9 of the 12 months; thus, the year ending September 30, 2015, is called "water year 2015".

\section{Datum}

Horizontal coordinate information is referenced to the North American Datum of 1983 (NAD 83). 


\section{Abbreviations}

$\begin{array}{ll}\text { AWQMN } & \text { Ambient Water Quality Monitoring Network } \\ \text { CIAT } & \text { 2-chloro-4-isopropylamino-6-amino-s-triazine } \\ \text { CWA } & \text { Clean Water Act } \\ \text { DO } & \text { dissolved oxygen } \\ \text { LT-MDL } & \text { long-term method detection level } \\ \text { MDL } & \text { method detection level } \\ \text { MDNR } & \text { Missouri Department of Natural Resources } \\ \text { MRL } & \text { minimum reporting level } \\ \text { NASQAN } & \text { National Stream Quality Assessment Network } \\ \text { NWIS } & \text { National Water Information System } \\ \text { NWOL } & \text { National Water Quality Laboratory } \\ \text { TMDL } & \text { total maximum daily load } \\ \text { USGS } & \text { U.S. Geological Survey }\end{array}$





\title{
Quality of Surface Water in Missouri, Water Year 2015
}

\author{
By Miya N. Barr and David C. Heimann
}

\section{Abstract}

The U.S. Geological Survey, in cooperation with the Missouri Department of Natural Resources, designed and operates a series of monitoring stations on streams and springs throughout Missouri known as the Ambient Water-Quality Monitoring Network. During water year 2015 (October 1, 2014, through September 30, 2015), data were collected at 74 stations72 Ambient Water-Quality Monitoring Network stations and 2 U.S. Geological Survey National Stream Quality Assessment Network stations. Dissolved oxygen, specific conductance, water temperature, suspended solids, suspended sediment, Escherichia coli bacteria, fecal coliform bacteria, dissolved nitrate plus nitrite as nitrogen, total phosphorus, dissolved and total recoverable lead and zinc, and select pesticide compound summaries are presented for 71 of these stations. The stations primarily have been classified into groups corresponding to the physiography of the State, primary land use, or unique station types. In addition, a summary of hydrologic conditions in the State including peak streamflows, monthly mean streamflows, and 7-day low flows is presented.

\section{Introduction}

The Missouri Department of Natural Resources (MDNR) is responsible for the implementation of the Federal Clean Water Act (CWA) in Missouri. Section 305(b) of the CWA requires that each State develop a water-quality monitoring program and periodically report the status of its water quality (U.S. Environmental Protection Agency, 1997). Water-quality status is described in terms of the suitability of the water for various uses, such as drinking, fishing, swimming, and support of aquatic life; these uses formally were defined as "designated uses" in State and Federal Regulations. Section 303(d) of the CWA requires certain waters be identified and total maximum daily loads (TMDLs) to be determined for waters that do not meet applicable water-quality standards for their designated uses (U.S. Environmental Protection Agency, 1997). Total maximum daily loads establish the maximum amount of an impairing substance that a waterbody can assimilate and still meet the water-quality standards. A TMDL addresses a single pollutant for each waterbody.
Missouri has an area of about 69,000 square miles $\left(\mathrm{mi}^{2}\right)$ and an estimated population of 6.08 million people (U.S. Census Bureau, 2016). Within Missouri, there are 24,491 miles (mi) of classified streams that support a variety of uses including wildlife, recreation, agriculture, industry, transportation, and public utilities. An estimated 11,029 mi of streams are adversely affected (impaired) by various physical changes or chemical contaminants to the point that criteria for at least one of the designated uses no longer can be met (Missouri Department of Natural Resources, 2014a). The impairment of about $6,283 \mathrm{mi}$ of assessed streams has been documented by data that meet the requirements of the 303(d) listing methodology of Missouri. Also, there are about 4,746 mi of classified, unassessed streams suspected of nonsupport for which some data have been collected, but the data are not of sufficient quality or quantity to officially rate the stream as impaired. Several of the unassessed streams suspected of nonsupport have been affected or modified by nonpoint or unknown sources (Missouri Department of Natural Resources, 2014a).

The U.S. Geological Survey (USGS), in cooperation with the MDNR, collects surface-water quality data pertaining to water resources in Missouri each water year (October 1 through September 30). These data, stored and maintained in the USGS National Water Information System (NWIS) database, are collected as part of the Missouri Ambient Water-Quality Monitoring Network (AWQMN) and constitute a source of reliable, impartial, and timely information for developing an enhanced understanding of the State's water resources. To make this information readily available, these data were published annually in the Water-Data Report series from water years 1964 through 2005 (U.S. Geological Survey, 1964-2005). Published data for the 2006 through 2010 water years can be accessed at http://wdr.water.usgs.gov (U.S. Geological Survey, 2006-2010). Beginning in water year 2011, discrete water-quality data were no longer published annually, but can be accessed on the NWIS database at http:// nwis.waterdata.usgs.gov/mo/nwis/qwdata.

The USGS, in cooperation with the U.S. Army Corps of Engineers, routinely collects suspended-sediment concentration data and various particle-size distribution data on the Missouri and Mississippi Rivers. These data assist with sediment transport and navigable channel assessments along the larger rivers. Sediment samples are collected at seven USGS streamflow-gaging stations within Missouri, but only four stations were used for this report because sediment and water 
quality data are collected at these included stations whereas at the three remaining stations only sediment data are collected. The suspended-sediment concentration data in this report are provided for comparison to the State's total suspended solids criteria.

The purpose of this report is to summarize surface-water quality data collected by the MDNR-USGS cooperative AWQMN for water year 2015. The annual summary of select constituents provides MDNR with current information to assess the quality of surface water within the State and ensure the objectives of the AWQMN are being met. This report is one in a series of annual summaries (Otero-Benitez and Davis, 2009a, 2009b; Barr, 2010, 2011, 2013, 2014, 2015; Barr and Schneider, 2014). Data on the physical characteristics and water-quality constituents in samples collected at 71 surface-water stations are presented in figures and tables. These 71 stations primarily were classified into groups corresponding to the physiography of the State (fig. 1), primary land use (fig. 2), or unique station types (fig.1).

\section{The Ambient Water-Quality Monitoring Network}

The USGS, in cooperation with the MDNR, designed and operates the cooperative AWQMN, which is a series of monitoring stations on streams and springs throughout Missouri (fig.1). Constituent concentration data from the AWQMN have been used to determine statewide water-quality status and long-term trends for a 15-year period (Barr and Davis, 2010) to meet information needs of State agencies involved in waterquality planning and management. The data collected also provide support for the design, implementation, and evaluation of preventive and remediation programs.

The objectives of the AWQMN are to (1) obtain data on the quality and quantity of surface water within the State; (2) provide a historical database of water-quality information that can be used by the State planning and management agencies to make informed decisions about anthropogenic effects (such as agriculture, mining, and urbanization) on the State's surface waters; and (3) provide for consistent methodology in data collection, laboratory analysis, and data reporting.

The MDNR and the USGS established a fixed-station AWQMN in 1964 with 18 stations, 5 of which are still currently (2016) being sampled. The number of stations within the AWQMN has varied since its inception because of the State's needs. During water year 2015, the AWQMN program consisted of 72 stations (71 primary stations and 1 alternate station). Alternate sampling stations have been established at streamflow-gaging stations within proximity of some primary AWQMN stations, and one such station (East Drywood Creek near Deerfield, 06901870) was sampled in October 2014 and September 2015 because of dry conditions at East Drywood Creek at Prairie State Park (06918730). In addition to the
AWQMN stations, water samples are collected by the USGS at two USGS National Stream Quality Assessment Network (NASQAN; a national water-quality sampling network operated by the USGS, see http://cida.usgs.gov/quality/rivers/ home). From these 74 total stations, 71 are included in this report (table 1; fig. 1). Three stations from the AWQMN did not fit in the station classes defined for this report (table 2) and were not included. The three excluded stations were Cuivre River near Troy (05514500) and Lamine River near Pilot Grove (06907300), both within the Ozark Plateaus border, and Lake Taneycomo at Branson (07053700) a station on a semiriverine system downstream from a major impoundment. Sampling frequency (table 1) is determined by several factors, including drainage basin size, potential effects from anthropogenic activities (such as agriculture, mining, and urbanization), history of chemical change, need for annual data, and cost. Each of the streams in the AWQMN is classified for one or more designated uses. For specific information on the designated uses applicable to the streams sampled in the AWQMN, refer to Missouri Department of Natural Resources (2014a; 2014b).

The unique eight-digit number used by the USGS to identify each surface-water station is assigned when a station first is first established. The complete eight-digit number for each station includes a two-digit prefix that designates the primary river system (05 is the Upper Mississippi River, 06 is the Missouri River, and 07 is the Lower Mississippi River) plus a six-digit downstream-order number; for example, the station number 05587455 indicates the station is on the Upper Mississippi River (05), and the remaining six digits (587455) locate the station in downstream order. In this system, the station numbers increase downstream along the main stem. A station on a tributary that enters between two main stem stations is assigned a station number between them.

Methods used for collecting and processing representative water-quality samples are presented in U.S. Geological Survey (variously dated). Onsite measurements of dissolved oxygen (DO), specific conductance, and water temperature were collected at each station according to procedures described in Wilde (variously dated). Samples were collected, analyzed for indicator bacteria (Escherichia coli $[$ E. coli $]$ and fecal coliform), and processed using the membrane filtration procedure described in Myers and others (2014). Methods used by the USGS for collecting and processing representative samples for nutrients, primary chemical constituents, trace elements, suspended solids, suspended sediment, and pesticide analyses are presented in detail in U.S. Geological Survey (2006), Guy (1969), and Wilde and others (2004). All chemical analyses were done by the USGS National Water Quality Laboratory (NWQL) in Lakewood, Colorado, according to procedures described in Patton and Kryskalla (2011), Patton and Truitt (1992), Garbarino, Kanagy, and Cree (2006), Fishman (1993), Sandstrom and others (2001), and Zaugg and others (1995). Suspended-sediment concentrations were computed according to procedures described in Guy (1969). 

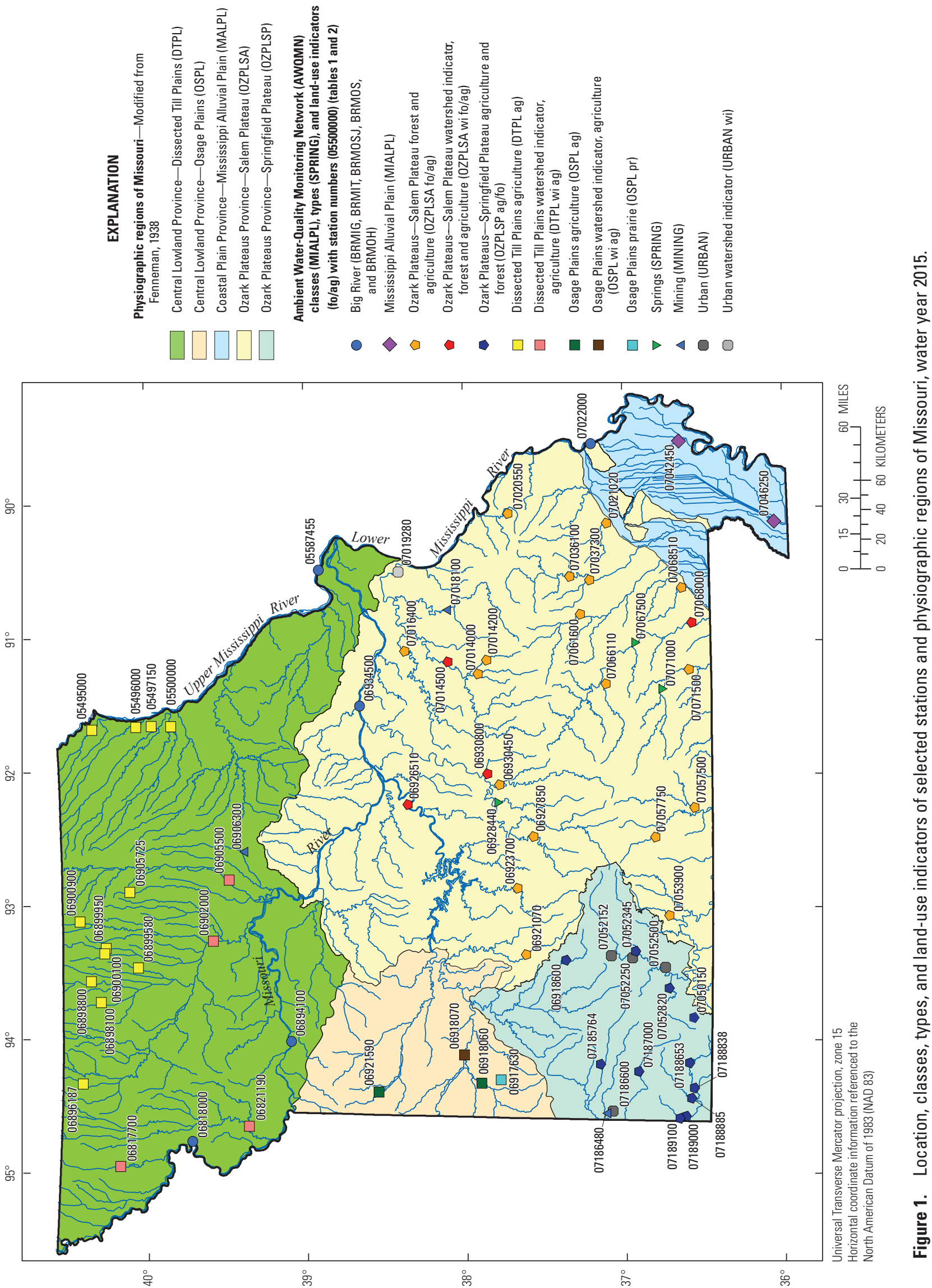
Table 1. U.S. Geological Survey station number, name, contributing drainage area, sampling frequency, and station class of 71 selected stations in Missouri, water year 2015.

[USGS, U.S. Geological Survey; mi², square mile; MO, Missouri; IL, Illinois; DTPL ag, Dissected Till Plains agriculture; BRMIG, Big River-Mississippi River below Grafton, Illinois; DTPL wi ag, Dissected Till Plains watershed indicator; BRMOSJ, Big River—Missouri River at St. Joseph, Missouri; BRMOS, Big River-Missouri River at Sibley, Missouri; MINING, mining; OSPL pr, Osage Plains prairie; OSPL ag, Osage Plains agriculture; OSPL wi ag, Osage Plains watershed indicator, agriculture; OZPLSP ag/fo, Ozark Plateaus - Springfield Plateau agriculture and forest; OZPLSA fo/ag, Ozark Plateaus - Salem Plateau forest and agriculture; OZPLSA wi fo/ag, Ozark Plateaus—Salem Plateau watershed indicator forest and agriculture; --, not applicable; SPRING, spring; BRMOH, Big River-Missouri River at Hermann, Missouri; URBAN wi, urban watershed indicator; BRMIT, Big River-Mississippi River at Thebes, Illinois; MIALPL, Mississippi Alluvial Plain; URBAN, urban; Water year 2015 is defined as October 1, 2014, through September 30, 2015.]

\begin{tabular}{|c|c|c|c|c|}
\hline $\begin{array}{l}\text { USGS station } \\
\text { number } \\
\text { (figs. } 1 \text { and } 3 \text { ) }\end{array}$ & Station name ${ }^{a}$ & $\begin{array}{l}\text { Contributing } \\
\text { drainage area } \\
\left(\mathrm{mi}^{2}\right)\end{array}$ & $\begin{array}{l}\text { Water year } \\
2015 \text { sampling } \\
\text { frequency }\end{array}$ & $\begin{array}{l}\text { USGS station } \\
\text { class } \\
\text { (fig. 1; table 2) }\end{array}$ \\
\hline 05495000 & Fox River at Wayland, MO & 400 & 6 & DTPL ag \\
\hline 05496000 & Wyaconda River above Canton, MO & 393 & 6 & DTPL ag \\
\hline 05497150 & North Fabius River near Ewing, MO & 471 & 6 & DTPL ag \\
\hline 05500000 & South Fabius River near Taylor, MO & 620 & 12 & DTPL ag \\
\hline $05587455^{\mathrm{b}}$ & Mississippi River below Grafton, IL & 171,300 & 12 & BRMIG \\
\hline 06817700 & Nodaway River near Graham, MO & 1,520 & 6 & DTPL wi ag \\
\hline $06818000^{\mathrm{b}}$ & Missouri River at St. Joseph, MO & 426,500 & 12 & BRMOSJ \\
\hline 06821190 & Platte River at Sharps Station, MO & 2,380 & 6 & DTPL wi ag \\
\hline 06894100 & Missouri River at Sibley, MO & 426,500 & 12 & BRMOS \\
\hline 06896187 & Middle Fork Grand River near Grant City, MO & 82.4 & 6 & DTPL ag \\
\hline 06898100 & Thompson River at Mount Moriah, MO & 891 & 8 & DTPL ag \\
\hline 06898800 & Weldon River near Princeton, MO & 452 & 7 & DTPL ag \\
\hline 06899580 & No Creek near Dunlap, MO & 34.0 & 10 & DTPL ag \\
\hline 06899950 & Medicine Creek near Harris, MO & 192 & 12 & DTPL ag \\
\hline 06900100 & Little Medicine Creek near Harris, MO & 66.5 & 12 & DTPL ag \\
\hline 06900900 & Locust Creek near Unionville, MO & 77.5 & 11 & DTPL ag \\
\hline 06902000 & Grand River near Sumner, MO & 6,880 & 12 & DTPL wi ag \\
\hline 06905500 & Chariton River near Prairie Hill, MO & 1,870 & 6 & DTPL wi ag \\
\hline 06905725 & Mussel Fork near Mystic, MO & 24.0 & 9 & DTPL ag \\
\hline 06906300 & East Fork Little Chariton River near Huntsville, MO & 220 & 6 & MINING \\
\hline 06917630 & East Drywood Creek at Prairie State Park, MO & 3.38 & 6 & OSPL pr \\
\hline $06917680^{c}$ & East Drywood Creek near Deerfield, MO & 358 & 2 & OSPL ag \\
\hline 06918070 & Osage River above Schell City, MO & 5,410 & 6 & OSPL wi ag \\
\hline 06918600 & Little Sac River near Walnut Grove, MO & 119 & 12 & OZPLSP ag/fo \\
\hline 06921070 & Pomme de Terre River near Polk, MO & 276 & 9 & OZPLSA fo/ag \\
\hline 06921590 & South Grand River at Archie, MO & 356 & 6 & OSPL ag \\
\hline 06923700 & Niangua River at Bennett Spring, MO & 441 & 6 & OZPLSA fo/ag \\
\hline 06926510 & Osage River below St. Thomas, MO & 14,580 & 6 & OZPLSA wi fo/ag \\
\hline 06927850 & Osage Fork of the Gasconade River near Lebanon, MO & 43.6 & 6 & OZPLSA fo/ag \\
\hline 06928440 & Roubidoux Spring at Waynesville, MO & -- & 6 & SPRING \\
\hline 06930450 & Big Piney River at Devil's Elbow, MO & 746 & 9 & OZPLSA fo/ag \\
\hline 06930800 & Gasconade River above Jerome, MO & 2,570 & 12 & OZPLSA wi fo/ag \\
\hline $06934500^{\mathrm{c}, \mathrm{d}}$ & Missouri River at Hermann, $\mathrm{MO}$ & 522,500 & 14 & BRMOH \\
\hline 07014000 & Huzzah Creek near Steelville, MO & 259 & 6 & OZPLSA fo/ag \\
\hline 07014200 & Courtois Creek at Berryman, $\mathrm{MO}$ & 173 & 6 & OZPLSA fo/ag \\
\hline 07014500 & Meramec River near Sullivan, MO & 1,475 & 12 & OZPLSA wi fo/ag \\
\hline 07016400 & Bourbeuse River above Union, MO & 808 & 9 & OZPLSA fo/ag \\
\hline 07018100 & Big River near Richwoods, MO & 735 & 10 & MINING \\
\hline 07019280 & Meramec River at Paulina Hills, MO & 3,920 & 11 & URBAN wi \\
\hline
\end{tabular}


Table 1. U.S. Geological Survey station number, name, contributing drainage area, sampling frequency, and station class of 71 selected stations in Missouri, water year 2015. - Continued

[USGS, U.S. Geological Survey; mi², square mile; MO, Missouri; IL, Illinois; DTPL ag, Dissected Till Plains agriculture; BRMIG, Big River-Mississippi River below Grafton, Illinois; DTPL wi ag, Dissected Till Plains watershed indicator; BRMOSJ, Big River-Missouri River at St. Joseph, Missouri; BRMOS, Big River-Missouri River at Sibley, Missouri; MINING, mining; OSPL pr, Osage Plains prairie; OSPL ag, Osage Plains agriculture; OSPL wi ag, Osage Plains watershed indicator, agriculture; OZPLSP ag/fo, Ozark Plateaus—Springfield Plateau agriculture and forest; OZPLSA fo/ag, Ozark Plateaus-Salem Plateau forest and agriculture; OZPLSA wi fo/ag, Ozark Plateaus—Salem Plateau watershed indicator forest and agriculture; --, not applicable; SPRING, spring; BRMOH, Big River-Missouri River at Hermann, Missouri; URBAN wi, urban watershed indicator; BRMIT, Big River-Mississippi River at Thebes, Illinois; MIALPL, Mississippi Alluvial Plain; URBAN, urban; Water year 2015 is defined as October 1, 2014, through September 30, 2015.]

\begin{tabular}{|c|c|c|c|c|}
\hline $\begin{array}{c}\text { USGS station } \\
\text { number } \\
\text { (figs. } 1 \text { and } 3 \text { ) }\end{array}$ & Station name ${ }^{a}$ & $\begin{array}{c}\text { Contributing } \\
\text { drainage area } \\
\left(\mathrm{mi}^{2}\right)\end{array}$ & $\begin{array}{l}\text { Water year } \\
2015 \text { sampling } \\
\text { frequency }\end{array}$ & $\begin{array}{l}\text { USGS station } \\
\text { class } \\
\text { (fig. 1; table 2) }\end{array}$ \\
\hline 07020550 & South Fork Saline Creek near Perryville, MO & 55.3 & 6 & OZPLSA fo/ag \\
\hline 07021020 & Castor River at Greenbriar, $\mathrm{MO}$ & 423 & 6 & OZPLSA fo/ag \\
\hline $07022000^{\mathrm{b}, \mathrm{d}}$ & Mississippi River at Thebes, IL & 713,200 & 14 & BRMIT \\
\hline 07036100 & St. Francis River near Saco, MO & 664 & 9 & OZPLSA fo/ag \\
\hline 07037300 & Big Creek at Sam A. Baker State Park, MO & 189 & 6 & OZPLSA fo/ag \\
\hline 07042450 & St. Johns Ditch at Henderson Mound, MO & 313 & 7 & MIALPL \\
\hline 07046250 & Little River Ditches near Rives, MO & 1,620 & 12 & MIALPL \\
\hline 07050150 & Roaring River Spring at Cassville, MO & -- & 6 & OZPLSP ag/fo \\
\hline 07052152 & Wilson Creek near Brookline, MO & 51 & 12 & URBAN \\
\hline 07052250 & James River near Boaz, MO & 462 & 6 & URBAN \\
\hline 07052345 & Finley Creek below Riverdale, MO & 261 & 12 & OZPLSP ag/fo \\
\hline 07052500 & James River at Galena, MO & 987 & 12 & URBAN \\
\hline 07052820 & Flat Creek below Jenkins, MO & 274 & 12 & OZPLSP ag/fo \\
\hline 07053900 & Swan Creek near Swan, MO & 148 & 6 & OZPLSA fo/ag \\
\hline 07057500 & North Fork River near Tecumseh, MO & 561 & 6 & OZPLSA fo/ag \\
\hline 07057750 & Bryant Creek below Evans, MO & 214 & 6 & OZPLSA fo/ag \\
\hline 07061600 & Black River below Annapolis, MO & 493 & 8 & OZPLSA fo/ag \\
\hline 07066110 & Jacks Fork above Two River, MO & 425 & 12 & OZPLSA fo/ag \\
\hline 07067500 & Big Spring near Van Buren, MO & -- & 4 & SPRING \\
\hline 07068000 & Current River at Doniphan, $\mathrm{MO}$ & 2,040 & 12 & OZPLSA wi fo/ag \\
\hline 07068510 & Little Black River below Fairdealing, MO & 194 & 6 & OZPLSA fo/ag \\
\hline 07071000 & Greer Spring at Greer, MO & -- & 3 & SPRING \\
\hline 07071500 & Eleven Point River near Bardley, MO & 793 & 6 & OZPLSA fo/ag \\
\hline 07185764 & Spring River above Carthage, MO & 425 & 12 & OZPLSP ag/fo \\
\hline 07186480 & Center Creek near Smithfield, MO & 303 & 9 & MINING \\
\hline 07186600 & Turkey Creek near Joplin, MO & 41.8 & 9 & URBAN \\
\hline 07187000 & Shoal Creek above Joplin, MO & 427 & 12 & OZPLSP ag/fo \\
\hline 07188653 & Big Sugar Creek near Powell, MO & 141 & 12 & OZPLSP ag/fo \\
\hline 07188838 & Little Sugar Creek near Pineville, MO & 195 & 12 & OZPLSP ag/fo \\
\hline 07188885 & Indian Creek near Lanagan, $\mathrm{MO}$ & 239 & 12 & OZPLSP ag/fo \\
\hline 07189000 & Elk River near Tiff City, MO & 872 & 12 & OZPLSP ag/fo \\
\hline 07189100 & Buffalo Creek at Tiff City, MO & 60.8 & 12 & OZPLSP ag/fo \\
\hline
\end{tabular}

aStation names obtained from U.S. Geological Survey National Water Information System database http://nwis.waterdata.usgs.gov/mo/nwis/ qwdata.

${ }^{\mathrm{b}}$ Additional water temperature and suspended-sediment samples collected in cooperation with the U.S. Army Corps of Engineers.

'Sampled as an alternate site when East Drywood Creek at Prairie State Park (06901870) was dry.

dStations 06934500 and 07022000 are not part of the Ambient Water-Quality Monitoring Network but were used in the report. Stations 06934500 and 07022000 are funded by the U.S. Geological Survey National Stream Quality Assessment Network. 


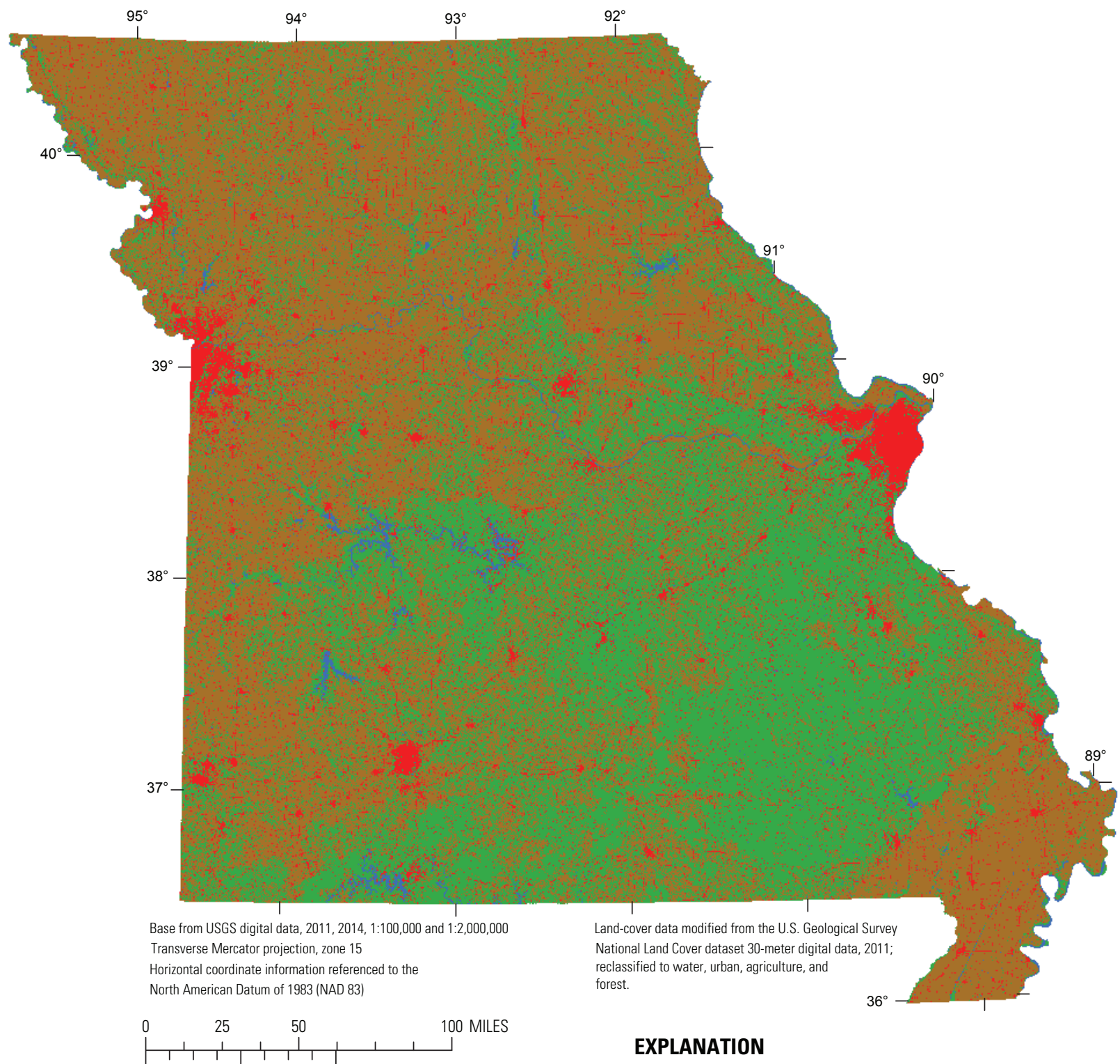

Primary land use in Missouri

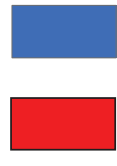

Open water-Lakes

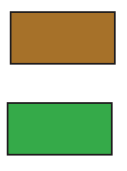

Agricultural land

Urban

Forest

Figure 2. Primary land use in Missouri.

\section{Laboratory Reporting Conventions}

The NWQL uses method reporting conventions (Childress and others, 1999) to establish the minimum concentration for which more than one qualitative measurement can be made. These reporting conventions are the minimum reporting level (MRL), the method detection level (MDL) and the laboratory reporting level (LRL). The MRL is defined by the NWQL as the smallest measured concentration of a substance that can be measured reliably using a given analytical method.
The MDL is the minimum concentration of a substance that can be measured and reported with 99 percent confidence that the concentration is greater than zero. A long-term method detection level (LT-MDL) is a detection level obtained by determining the standard deviation of 24 or more MDL spiked-sample measurements for an extended period. The LRL is computed as twice the LT-MDL. Pesticide data in this report that are not reported as less than $(<)$ the LRL and are graphically displayed below the LRL are estimated values (Childress and others, 1999) and not considered detections. 
Table 2. U.S. Geological Survey station classes and number of stations in each class, water year 2015.

\begin{tabular}{|c|c|c|}
\hline $\begin{array}{c}\text { USGS stations class } \\
\text { (fig. 1) }\end{array}$ & Description & $\begin{array}{l}\text { Number of } \\
\text { stations }\end{array}$ \\
\hline BRMIG & Big River-Mississippi River below Grafton, IL & 1 \\
\hline BRMIT & Big River-Mississippi River at Thebes, IL & 1 \\
\hline BRMOSJ & Big River-Missouri River at St. Joseph, MO & 1 \\
\hline BRMOS & Big River-Missouri River at Sibley, MO & 1 \\
\hline BRMOH & Big River-Missouri River at Hermann, MO & 1 \\
\hline MIALPL & Mississippi Alluvial Plain & $2^{\mathrm{a}}$ \\
\hline OZPLSA fo/ag & Ozark Plateaus - Salem Plateau forest and agriculture & 18 \\
\hline OZPLSA wi fo/ag & Ozark Plateaus_-Salem Plateau watershed indicator, forest and agriculture & 4 \\
\hline OZPLSP ag/fo & Ozark Plateaus - Springfield Plateau agriculture and forest & 11 \\
\hline DTPL ag & Dissected Till Plains agriculture & 12 \\
\hline DTPL wi ag & Dissected Till Plains watershed indicator, agriculture & 4 \\
\hline OSPL ag & Osage Plains agriculture & 2 \\
\hline OSPL wi ag & Osage Plains watershed indicator, agriculture & 1 \\
\hline OSPL pr & Osage Plains prairie & 1 \\
\hline SPRING & Springs & 3 \\
\hline MINING & Mining & 3 \\
\hline URBAN & Urban & 4 \\
\hline URBAN wi & Urban watershed indicator & 1 \\
\hline
\end{tabular}

\section{Data Analysis Methods}

The distribution of select constituent data was graphically displayed using side-by-side boxplots (box and whiskers distributions; Helsel and Hirsch, 2002). The plots show the center of the data (median, the center line of the boxplot), the variation (interquartile range [25th to 75 th percentiles] or the height of the box), the skewness (quartile skew, which is the relative size of the box halves), the spread (upper and lower adjacent values are the vertical lines or whiskers), and the presence or absence of unusual values or outliers. If the median equals the 25th and 75th percentiles, the boxplot is represented by a single horizontal line. Boxplots with censored data (suspended solids, dissolved nitrate plus nitrite as nitrogen, total phosphorus, and dissolved and total recoverable lead and zinc) were modified by making the lower limit of the box equal to the MRL or LT-MDL. For pesticide concentration distributions, censored concentrations (reported as less than the LRL) were included in each distribution as a concentration value equal to the LRL. For some samples, pesticide concentrations are reported as estimated values (Childress and others, 1999), which are included in the distribution as a concentration that is plotted below the LRL and above the LT-MDL.

\section{Station Classification for Data Analysis}

The stations primarily were classified in groups corresponding to the physiography of the State (fig. 1), primary land use (fig. 2), or unique station classes and types (fig. 1). The physiography-based groups include the Dissected Till Plains (DTPL) in the north, the Osage Plains (OSPL) in the west, the Mississippi Alluvial Plain (MIALPL) in the southeast, and between them the Ozark Plateaus. The Ozark Plateaus (Fenneman, 1938) were further subdivided into two distinct groups based on physiographic location - the Salem Plateau (OZPLSA) and the Springfield Plateau (OZPLSP) (fig.1). Primary land use considered for station classification included agriculture, forest, urban, and mining, but mining is not shown at the scale of the map (fig. 2). Station classes 
specifically designated by land-use groups include mining (MINING) and urban (URBAN) stations, whereas station classes designated with unique station types refer to springs (SPRING) and the stations on the Mississippi River (BRMIG and BRMIT) and the Missouri River (BRMOSJ, BRMOS and $\mathrm{BRMOH})$, also referred to in this report as the "Big River stations" (fig. 1).

Some additional variability caused by differences in drainage area and land use was observed within physiographic regions; therefore, contributing drainage area (table 1) and land-use indicators were used to develop a complete set of classes. The land-use indicator provides a subclassification for stations in similar regions with different land uses (fig. 1; table 2). The land-use indicators include watershed indicator stations (wi), which are the most downstream stations in a large watershed and are defined for the purposes of this report as a drainage area greater than $1,000 \mathrm{mi}^{2}$, and the secondary land-use indicators, forest (fo); agriculture (ag); and prairie (pr). Unlike data from secondary land-use indicator sites, observations and analyses from watershed indicator stations can be interpreted as being representative of the general condition of the watershed rather than affected by a specific land use. In some instances, agriculture and forest land uses were present; therefore, the convention was to mention them in predominant order. The agriculture and forest $(\mathrm{ag} / \mathrm{fo})$ land-use indicator, for example, implies that the dominant land use of the watershed is agriculture, although a substantial part of the land use is forest.

\section{Hydrologic Conditions}

Surface-water streamflow varies seasonally in Missouri and tends to reflect precipitation patterns. During water year 2015 , the average annual precipitation of the conterminous United States was 1.13 inches (in.) above the 20th century average of 31.07 in. (National Oceanic and Atmospheric Administration, 2016a). Precipitation in Missouri during water year 2015 was $48.54 \mathrm{in}$. and greater than the 20th century State precipitation average of $40.79 \mathrm{in}$. (National Oceanic and Atmospheric Administration, 2016b).

The selection of streamflow-gaging stations (hereinafter referred to as "streamgages") used to describe the variation in hydrologic conditions was based on their geographical distribution across the State and a period of record of at least 45 years. This summary of statewide hydrologic condition data is a legacy of information that was previously provided in the annual Water-Data Reports (U.S. Geological Survey, 1964-2005). Stations used for the hydrologic summary are identified in figure 3.

Six streamgages distributed throughout the State were selected to represent water year 2015 monthly mean streamflow and the long-term mean monthly streamflow (fig. 4). Monthly mean streamflow is the arithmetic mean of daily streamflow for a given month. For comparison to water year 2015, a long-term mean was attained from all monthly mean streamflows for the available period of record. Of these six streamgages, three $(05495000,06921590$, and 07052500) are part of the AWQMN and the remaining three sreamgages $(06897500,06933500$, and 07067000$)$ only record streamflow and are not part of the AWQMN (table 1; figs. 3, 4). Monthly

Table 3. Peak streamflow for water year 2015 and periods of record for selected streamgages, in Missouri.

[USGS, U.S. Geological Survey; ft³/s, cubic feet per second; MO, Missouri; IL, Illinois; Water year 2015 is defined as October 1, 2014, through September 30, 2015]

\begin{tabular}{|c|c|c|c|c|c|}
\hline \multirow{2}{*}{$\begin{array}{l}\text { USGS station } \\
\text { number }^{\mathrm{a}} \\
\text { (figs. } 1 \text { and } 3 \text { ) }\end{array}$} & \multirow{2}{*}{$\begin{array}{c}\text { Station name }{ }^{b} \\
\text { (period of record used for statistical summaries in } \\
\text { water years) }\end{array}$} & \multicolumn{2}{|c|}{2015 water year } & \multicolumn{2}{|c|}{ Long-term period of record } \\
\hline & & $\begin{array}{l}\text { Peak } \\
\text { streamflow } \\
\left(\mathrm{ft}^{3} / \mathrm{s}\right)\end{array}$ & Date & $\begin{array}{c}\text { Peak } \\
\text { streamflow } \\
\left(\mathrm{ft}^{3} / \mathrm{s}\right)\end{array}$ & Date \\
\hline 05495000 & Fox River at Wayland, MO (1922-2015) & 14,400 & June 26,2015 & 26,400 & Apr. 22,1973 \\
\hline 05587450 & Mississippi River at Grafton, IL (1987-2015) & 409,000 & June 30,2015 & 598,000 & Aug. 1, 1993 \\
\hline 06905500 & Chariton River near Prairie Hill, MO (1929-2015) & 34,300 & June 28,2015 & 38,400 & July 27,2008 \\
\hline 06933500 & Gasconade River at Jerome, MO (1903-2015) & 56,900 & June 22,2015 & 138,000 & Aug. 7, 2013 \\
\hline 06934500 & Missouri River at Hermann, MO (1958-2015) & 321,000 & July 10,2015 & 750,000 & July 31,1993 \\
\hline 07019000 & Meramec River near Eureka, MO (1904-2015) & 50,600 & June 22, 2015 & 145,000 & Dec. 6,1982 \\
\hline 07022000 & Mississippi River at Thebes, IL (1933-2015) & 732,000 & June 23,2015 & 996,000 & Aug. 7, 1993 \\
\hline 07057500 & North Fork River near Tecumseh, MO (1945-2015) & 13,700 & July 10,2015 & 133,000 & Nov. 19,1985 \\
\hline 07068000 & Current River at Doniphan, MO (1921-2015) & 29,100 & July 12,2015 & 122,000 & Dec. 3, 1982 \\
\hline
\end{tabular}

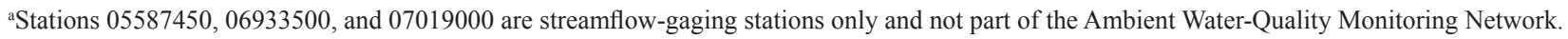

${ }^{\mathrm{b}}$ Station name obtained from the U.S. Geological Survey National Water Information System database http://nwis.waterdata.usgs.gov/mo/nwis/qwdata. 


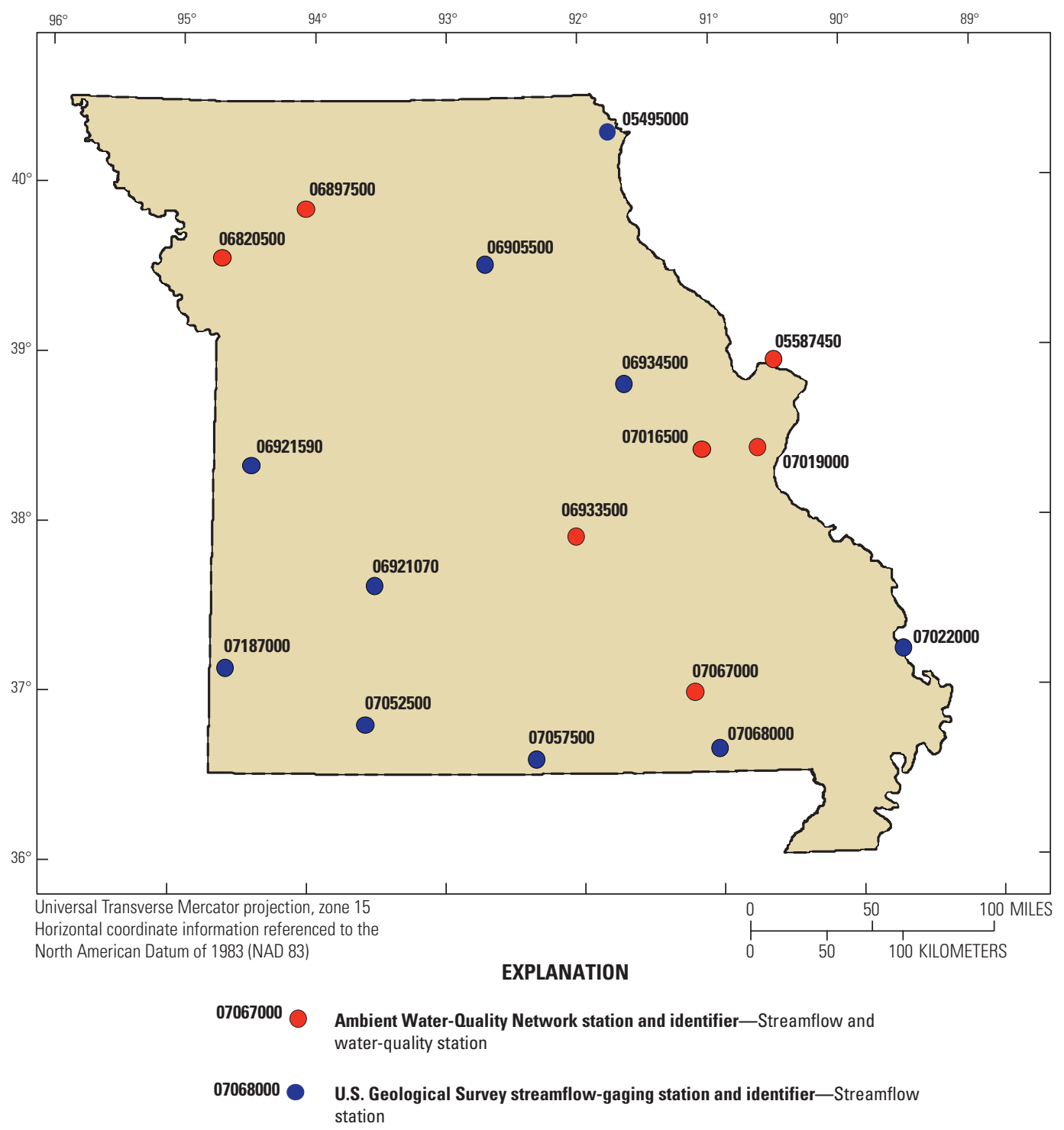

Figure 3. Location of selected streamflow-gaging stations used for summary of hydrologic conditions within Missouri, water year 2015.

mean streamflows for water year 2015 generally were lower than the long-term mean from November 2014 through April 2015 for the northern and central streamgages $(05495000$, 06897500,06921590 , and 06933500) and from November 2014 through February 2015 at the remaining streamgages (07052500 and 07067000). During June 2015 through September 2015, generally mean streamflows were substantially higher than the long-term mean at all six streamgages. The largest differences in monthly mean streamflow and longterm mean streamflows were noted at 05495000, 06897500, 06933500, and 07052500 during July and August 2015 (fig. 4).

Peak streamflow for water year 2015 and the periods of record are presented for nine streamgages (table 3 ). The peak streamflow values presented in table 3 were less than the peak streamflow for the period of record at all stations. The 7-day low flow for the period of record and water year 2015, and the minimum daily mean flow for the period of record are presented for selected stations in table 4. The 7-day low flow (the smallest values of mean streamflow computed during any 7-consecutive days during the analysis period) and minimum daily mean flows recorded during water year 2015 did not exceed historical records for the stations.

\section{Distribution, Concentration, and Detection Frequency of Select Constituents}

The analyses presented in this report include the following constituents: DO, specific conductance, water temperature, suspended solids, suspended sediment, E. coli bacteria, fecal coliform bacteria, dissolved nitrate plus nitrite as nitrogen 
Table 4. Seven-day low flow for water year 2015, period of record 7-day low flow, minimum daily mean streamflow for water year 2015, and period of record minimum daily mean streamflow for selected streamgages in Missouri.

[USGS, U.S. Geological Survey; ft³/s, cubic feet per second;; MO, Missouri; Water year 2015 is defined as October 1, 2014, through September 30, 2015]

\begin{tabular}{|c|c|c|c|c|c|c|}
\hline \multirow{2}{*}{$\begin{array}{l}\text { USGS station } \\
\text { number }^{\mathrm{a}} \\
\text { (figs. } 1 \text { and } 3 \text { ) }\end{array}$} & \multirow{2}{*}{$\begin{array}{c}\text { Station name }{ }^{\mathrm{b}} \\
\text { (period of record in water years) }\end{array}$} & \multicolumn{2}{|c|}{$\begin{array}{c}\text { 7-day } \\
\text { low flow } \\
\left.\text { (ft }{ }^{3} / \mathrm{s}\right)\end{array}$} & \multicolumn{3}{|c|}{$\begin{array}{l}\text { Minimum daily mean streamflow } \\
\qquad\left(\mathrm{ft}^{3} / \mathrm{s}\right)\end{array}$} \\
\hline & & 2015 & $\begin{array}{l}\text { Period of } \\
\text { record }\end{array}$ & 2015 & $\begin{array}{l}\text { Period of } \\
\text { record }\end{array}$ & Date \\
\hline 05495000 & Fox River at Wayland, MO (1922-2015) & 13.6 & 0 & 11.0 & 0 & Sept. 10,1930 \\
\hline 06820500 & Platte River near Agency, MO (1933-2015) & 215 & 0 & 195 & 0 & July 19, 1934 \\
\hline 06921070 & Pomme de Terre River near Polk, MO (1969-2015) & 12.4 & 0.21 & 9.70 & 0.17 & Aug. 13, 2012 \\
\hline 07016500 & Bourbeuse River near Union, MO (1921-2015) & 43.1 & 13 & 24.0 & 12 & Oct. 10,1956 \\
\hline 07067000 & Current River at Van Buren, MO (1912-2015) & 819 & 479 & 748 & 476 & Oct. 8,1956 \\
\hline 07187000 & Shoal Creek above Joplin, MO (1942-2015) & 87.3 & 16 & 73.0 & 15 & Sept. 7, 1954 \\
\hline
\end{tabular}

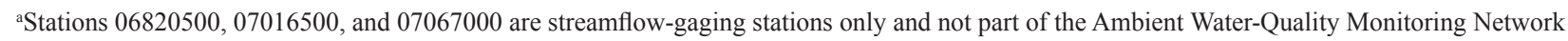
(AWQMN).

${ }^{b}$ Station name obtained from the U.S. Geological Survey National Water Information System database http://nwis.waterdata.usgs.gov/mo/nwis/qwdata.

(hereinafter referred to as "nitrate plus nitrite"), total phosphorus, and dissolved and total recoverable lead and zinc. Boxplots of these constituents are presented for the different station classes (figs. 5-8). In addition, pesticide data were analyzed from seven stations from six classes (fig. 9). Three Big River stations and classes (05587455 in class BRMIG; 06934500 in class BRMOH; and 07022000 in class BRMIT) had pesticide analyses completed as part of the NASQAN program, which began using a new method for pesticide analyses during water year 2013 (Sandstrom and Wilde, 2014). Many constituents available using the new method were similar to the constituents available with traditional pesticide sampling methods used for the AWQMN stations (06918070 in class OSPL wi ag; 07042450 and 07046250 in class MIALPL; 07052250 in class URBAN; fig. 1), but because of the different method, some have different LRLs (fig. 9). Of the 85 pesticide constituents analyzed using traditional pesticide sample methods for the AWQMN and the 228 pesticide constituents analyzed as part of the NASQAN program during water year 2015,15 had concentrations that were larger than their LRL in at least one sample, were common to both sampling methods, and are presented in this report: 2-chloro-4-isopropylamino6-amino-s-triazine (CIAT; a degradation product of atrazine), acetochlor, atrazine, dimethoate, fipronil, hexazinone, metalaxyl, metolachlor, metribuzin, prometon, prometryn, propanil, simazine, tebuthiuron, and terbuthylazine (fig. 9). Missouri water-quality standards are not shown on the graphs because these standards are not applicable to all streams in the AWQMN. For specific information on Missouri water-quality standards, refer to Missouri Department of Natural Resources (2014b).

\section{Distribution of Physical Properties, Suspended- Solids Concentration, Suspended-Sediment Concentration, and Indicator Bacteria Density}

The physical properties analyzed for this report were DO, specific conductance, and water temperature. The median DO, in percent saturation, ranged from 64 to 110 percent (fig. 5). Samples from OSPL wi ag stations had the lowest median DO percent saturation values, whereas samples from URBAN stations had the highest median DO (fig. 5). Median specific conductance values varied substantially among the station classes (fig. 5), ranging from 112 microsiemens per centimeter at 25 degrees Celsius $\left(\mu \mathrm{S} / \mathrm{cm}\right.$ at $\left.25^{\circ} \mathrm{C}\right)$ at the OSPL pr station to $830 \mu \mathrm{S} / \mathrm{cm}$ at $25^{\circ} \mathrm{C}$ at the BRMOSJ station. Median water temperature ranged from 14.3 to 18.4 degrees Celsius; the smallest median temperature was measured at the SPRING stations and the largest was measured at OSPL ag stations (fig. 5). The interquartile range in water temperature at the SPRING stations was much smaller than at any other station class.

Suspended solids and suspended sediment are measures of the solid material suspended in the water column. These two measures are not considered directly comparable because of differences in collection and analytical techniques. Suspended-solids concentrations were determined for all station classes except BRMIT and BRMOH. Median suspendedsolids concentrations varied considerably among all station classes, ranging from 15 to 180 milligrams per liter $(\mathrm{mg} / \mathrm{L}$; fig. 5). Samples collected at the OZPL (SA fo/ag, SA wi fo/ag, and SP ag/fo), OSPL ag, SPRING, MINING, and URBAN 
05495000 Fox River at Wayland

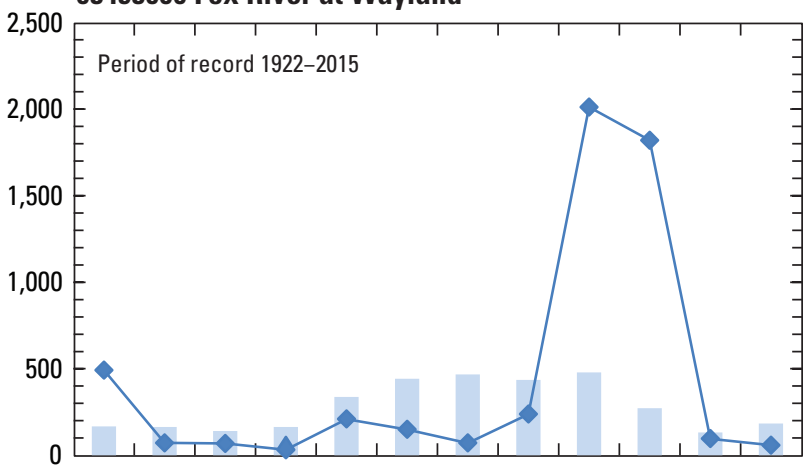

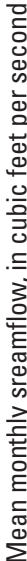
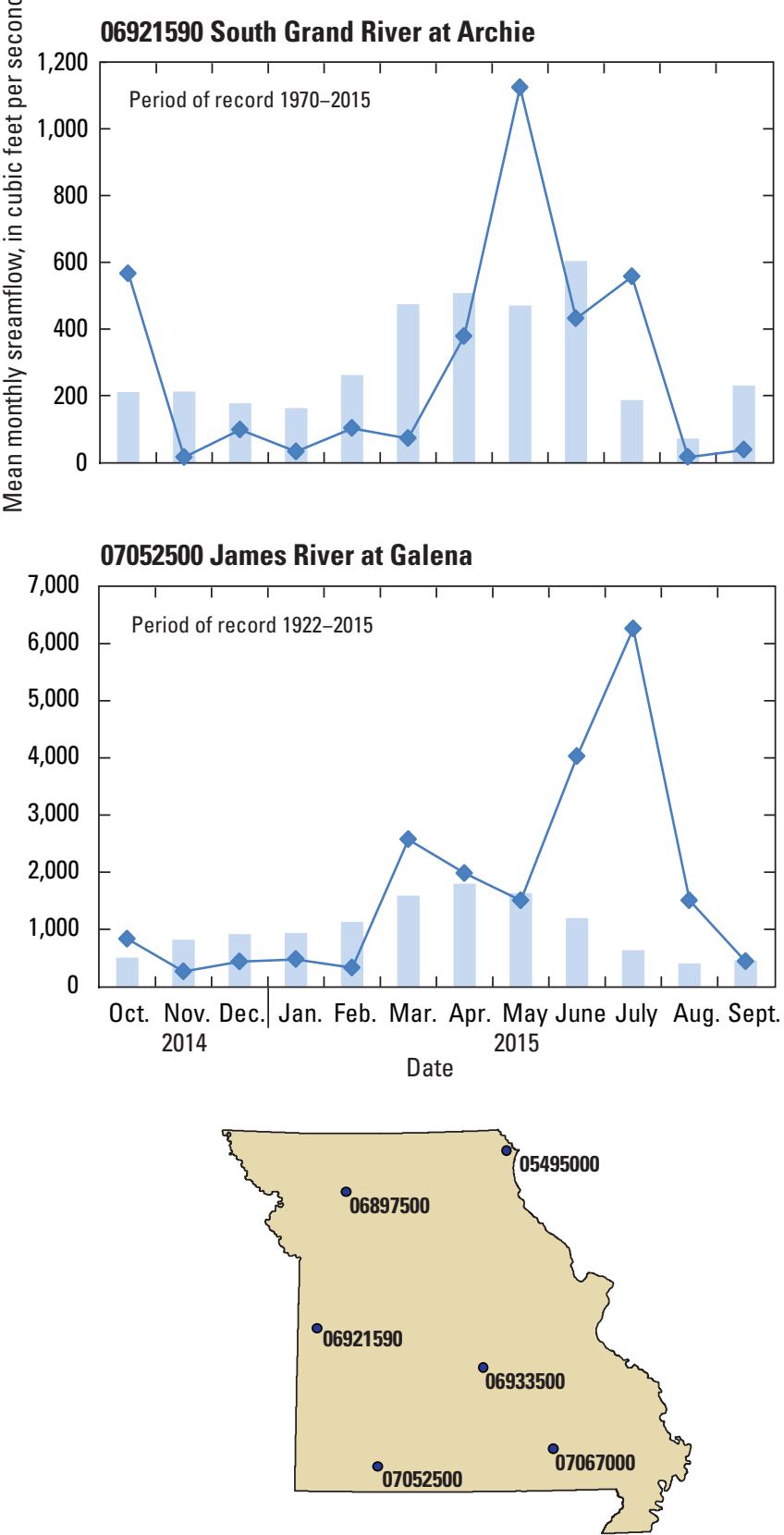

06897500 Grand River near Gallatin

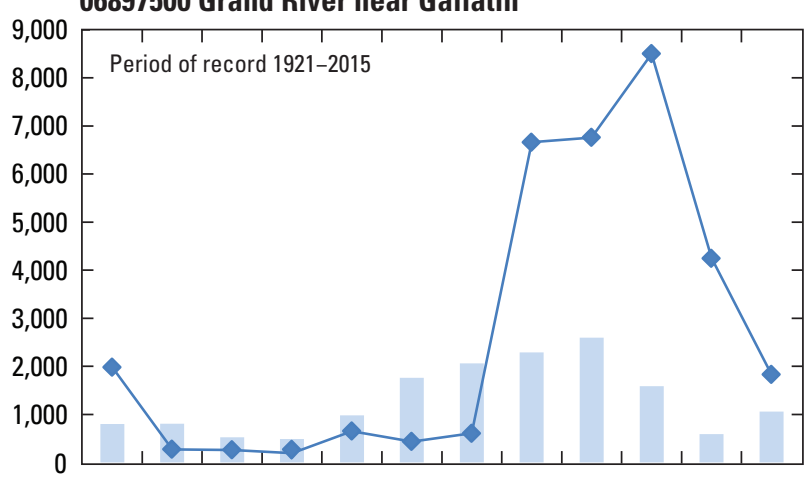

06933500 Gasconade River at Jerome

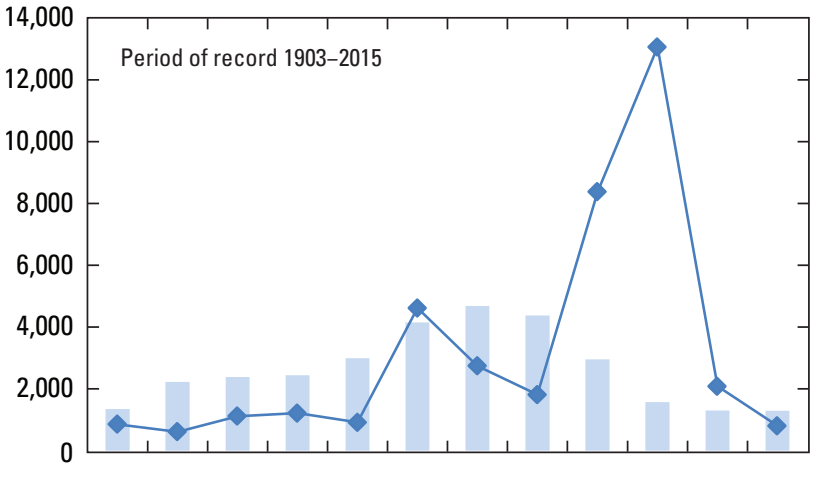

07067000 Current River at Van Buren

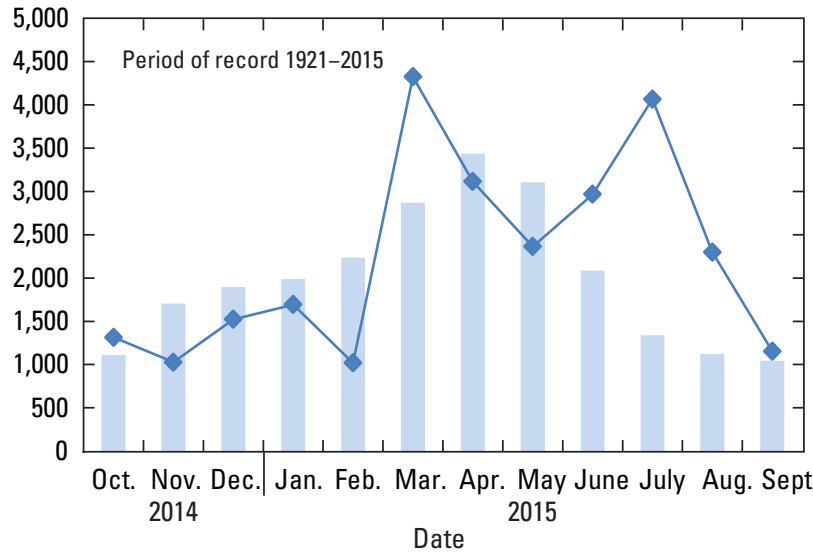

EXPLANATION

Figure 4. Monthly mean streamflow for water year 2015 and long-term mean monthly streamflow at six representative streamgages, in Missouri. 

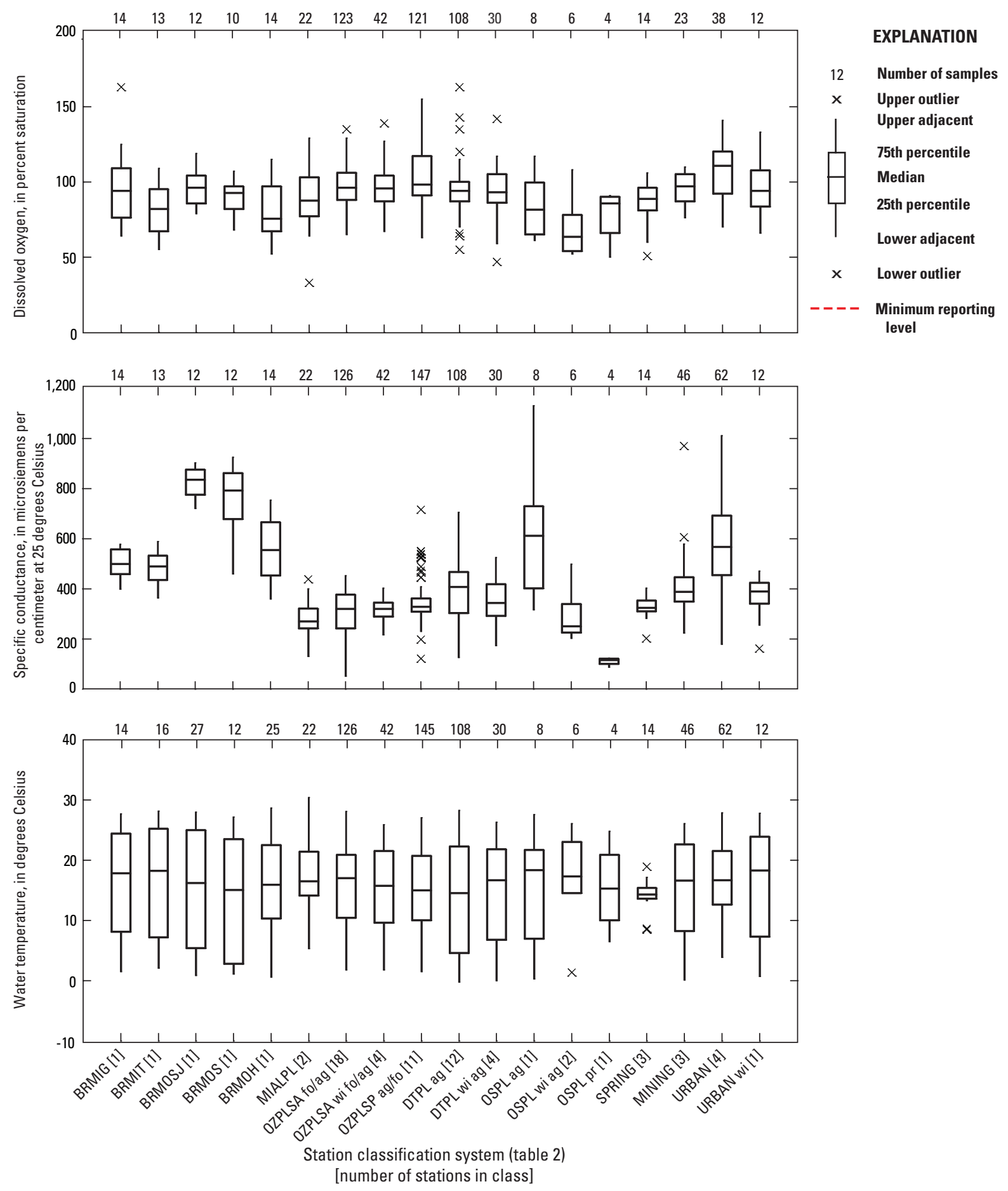

Figure 5. Distribution of physical properties, suspended-solids concentrations, and suspended-sediment concentrations, in samples from 71 stations in Missouri, water year 2015. 

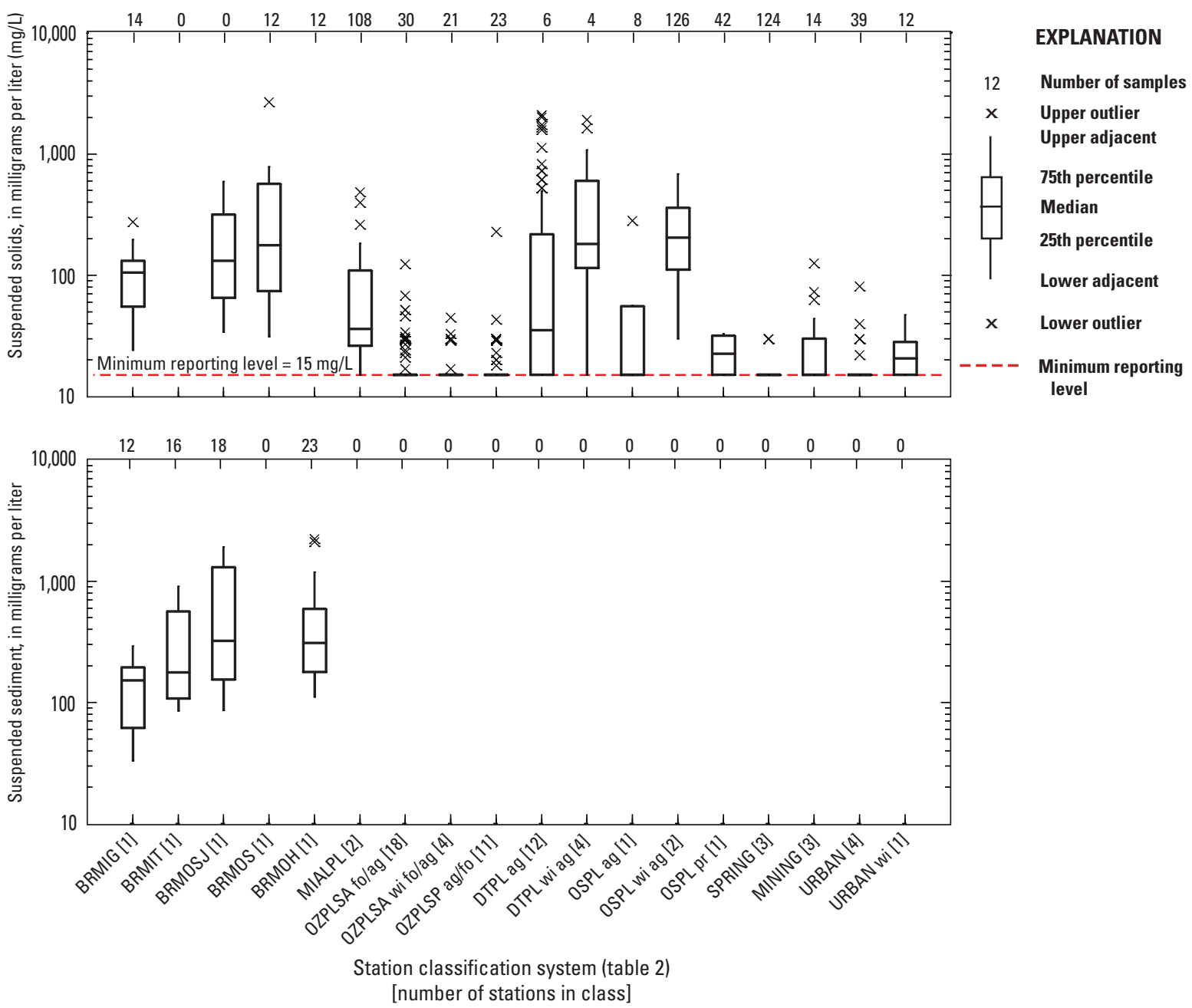

Figure 5. Distribution of physical properties, suspended-solids concentrations, and suspended-sediment concentrations, in samples from 71 stations in Missouri, water year 2015.-Continued

stations had median concentrations less than the MRL. The DTPL wi ag stations had the largest median suspended-solids concentrations $(180 \mathrm{mg} / \mathrm{L})$. Suspended-sediment concentrations were determined at four Big River stations (fig. 5). The suspended-sediment data used in this report consist of composited cross-sectional concentrations and average crosssectional concentrations computed from four (Missouri River stations) or five (Mississippi River at Thebes, IL) depthintegrated (Edwards and Glysson, 1999) samples within the cross section. Additional suspended-sediment concentrations from individual depth-integrated samples within cross-sections are available through the NWIS database (http://nwis.waterdata.usgs.gov/mo/nwis/qwdata). Median suspended-sediment concentrations ranged from $151 \mathrm{mg} / \mathrm{L}$ at BRMIG to $320 \mathrm{mg} / \mathrm{L}$ at BRMOH (fig. 5).

Median E. coli and fecal coliform bacteria densities varied considerably among all station classes (fig. 6). Median E. coli densities ranged from 12 to 2,240 colonies per 100 milliliters of water, and fecal coliform bacteria densities ranged from 25 to 1,980 colonies per 100 milliliters of water (fig. 6). The smallest median densities were in samples collected at OZPLSA wi fo/ag and SPRING stations, whereas the largest median densities were in samples collected at the station in the OSPL pr class (fig. 6).

\section{Distribution of Dissolved Nitrate plus Nitrite and Total Phosphorus Concentrations}

Samples were collected at all stations for the analysis of nutrients, including dissolved nitrate plus nitrite and total phosphorus. Median dissolved nitrate plus nitrite and total phosphorus concentrations varied considerably among all station classes (fig. 7), ranging from 0.04 to $3.97 \mathrm{mg} / \mathrm{L}$ for nitrate plus nitrite and 0.02 to $0.74 \mathrm{mg} / \mathrm{L}$ for total phosphorus. The smallest median dissolved nitrate plus nitrite concentrations were detected at the OSPL pr station, and the largest 

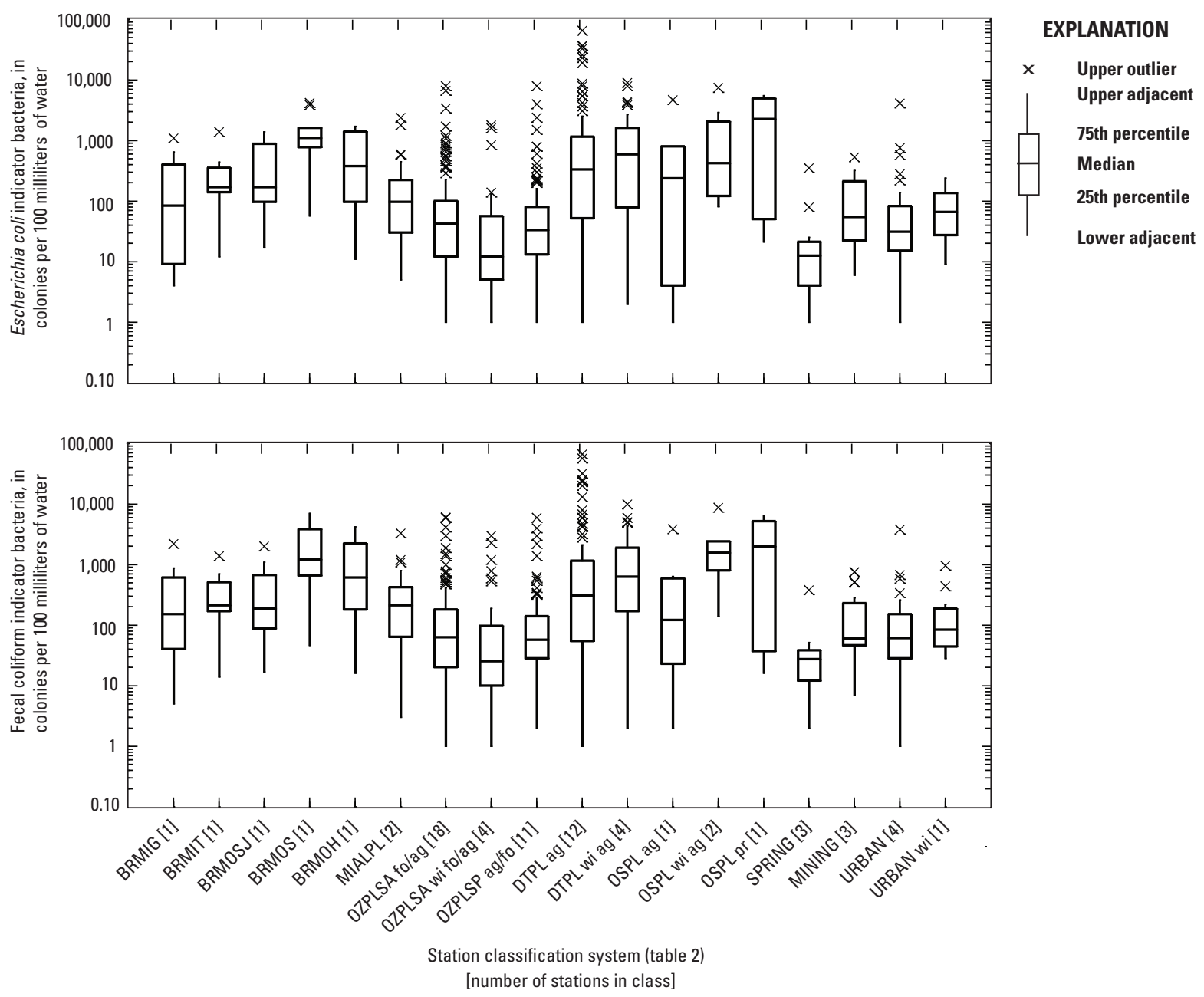

Figure 6. Distribution of indicator bacteria densities in samples from 71 stations in Missouri, water year 2015.

concentrations were detected in samples collected at URBAN stations (fig. 7). The smallest median total phosphorus concentrations were detected at the OZPLSA (fo/ag and wi fo/ag) and SPRING stations, all of which had median values equal to the LT-MDL, and the largest median concentration was at the BRMOH station (fig. 7).

\section{Distribution of Dissolved and Total Recoverable Lead and Zinc Concentrations}

Samples were collected for the analysis of dissolved and total recoverable trace elements, including lead and zinc. No dissolved or total recoverable lead and zinc samples were collected at the BRMIT and BRMOH stations. Median concentration ranges were 0.04 to 0.40 micrograms per liter $(\mu \mathrm{g} / \mathrm{L})$ of dissolved lead, 0.10 to $10.8 \mu \mathrm{g} / \mathrm{L}$ of total recoverable lead, 2.0 to $9.3 \mu \mathrm{g} / \mathrm{L}$ of dissolved zinc, and 2.0 to $38.8 \mu \mathrm{g} / \mathrm{L}$ of total recoverable zinc (fig. 8).

The smallest median concentrations of dissolved lead were detected at the LT-MDL in samples collected at BRMOSJ, BRMOS, OZPLSA (wi fo/ag, ag/fo), DTPL wi ag, and SPRING stations; MINING had the highest median concentration (fig. 8). Median dissolved zinc concentrations were detected at the LT-MDL for all classes except, OSPL pr (one sample), MINING, and URBAN; MINING had the highest median concentration. The largest median concentration of 


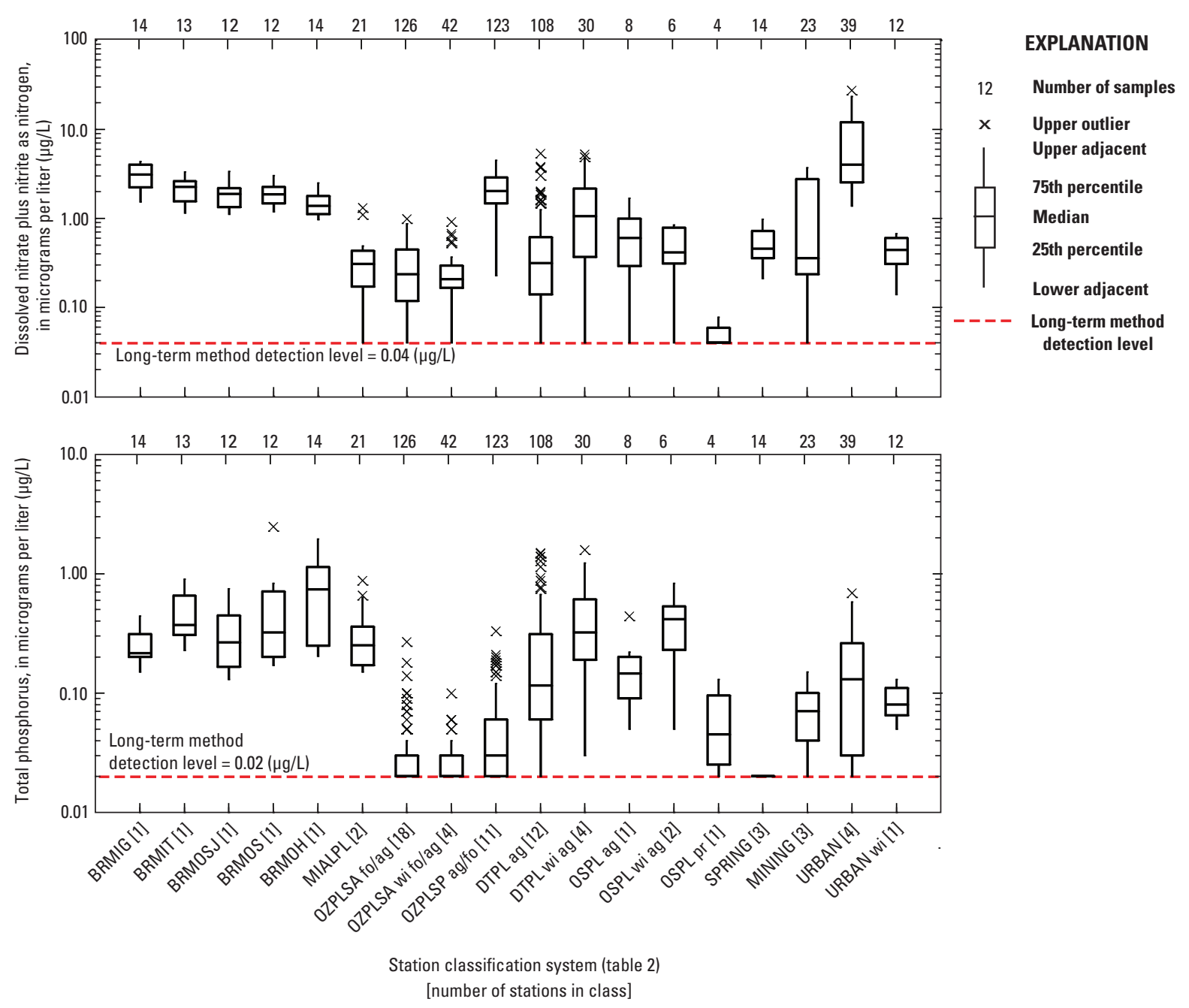

Figure 7. Distribution of dissolved nitrate plus nitrite as nitrogen and total phosphorus concentrations in samples from 71 stations in Missouri, water year 2015.

total recoverable lead and total recoverable zinc was detected at the OSPL wi ag station.

\section{Concentration and Detection Frequency of Select Pesticides from Selected Stations}

Samples for the analysis of dissolved pesticides were collected at seven stations in the AWQMN, including three of the five Big River stations (BRMIG, BRMIT, and BRMOH), two stations in the MIALPL, one OSPL wi ag station, and one URBAN station. Data from 15 compounds analyzed at all stations and detected at concentrations greater than the LRL at 1 or more stations are presented graphically in this report (fig. 9). The most frequently detected pesticides were atrazine, CIAT, metolachlor, prometon, simazine and metribuzin. Concentrations of the herbicide alachlor, a commonly detected herbicide in 2008-2014 (Otero-Benitez and Davis, 2009a, 2009b; Barr, 2010, 2011, 2013, 2014, 2015; Barr and Schneider, 2014) was not detected at levels larger than the LRL in samples collected in 2015. The concentrations for all pesticide compounds analyzed for all stations were less than $1.00 \mu \mathrm{g} / \mathrm{L}$ except atrazine and metolachlor. The atrazine concentrations ranged from 0.006 to $19.5 \mu \mathrm{g} / \mathrm{L}$, and metolachlor concentrations ranged from 0.009 to $10.9 \mu \mathrm{g} / \mathrm{L}$. Of the 15 pesticide compounds with concentrations larger than the LRL, 9 had the largest concentrations at the MIALPL stations (fig. 9). 


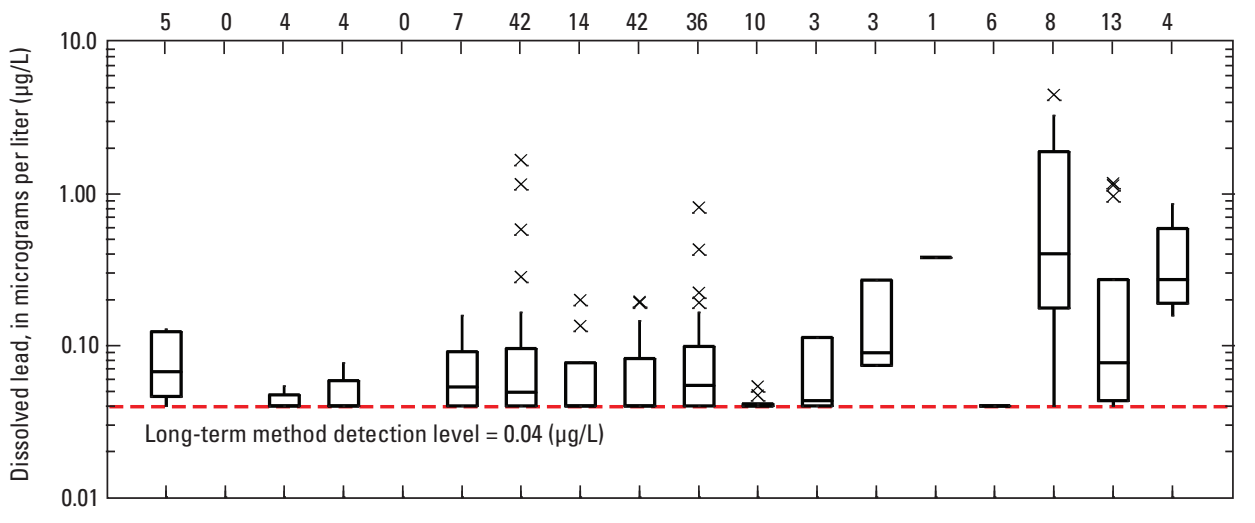

EXPLANATION

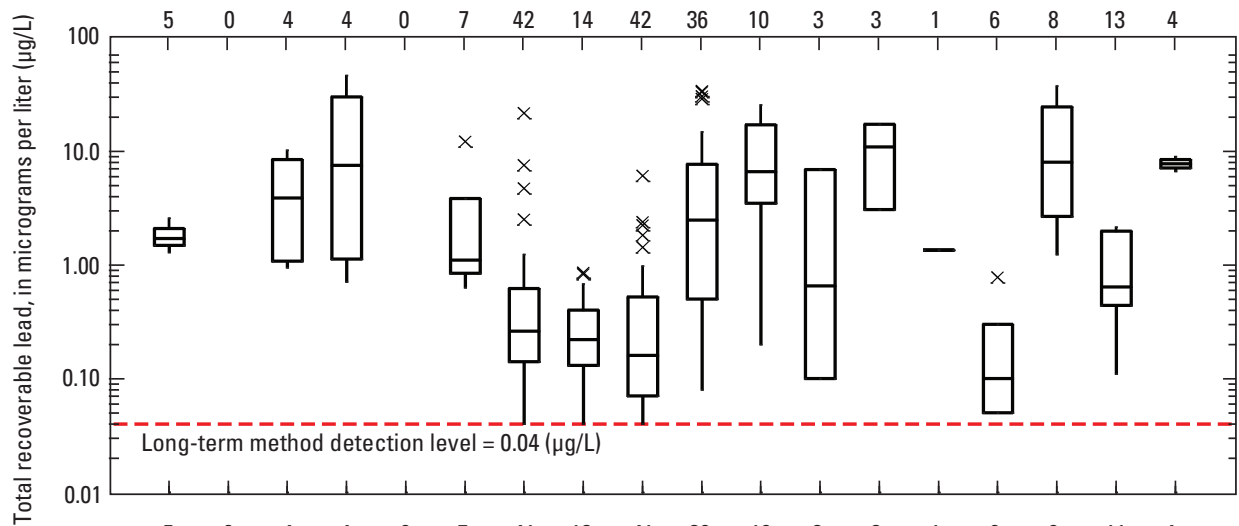

4 Number of samples

X Upper outlier Upper adjacent

75th percentile

Median

25th percentile

Lower adjacent

$x \quad$ Lower outlier

- - - - Long-term method detection level
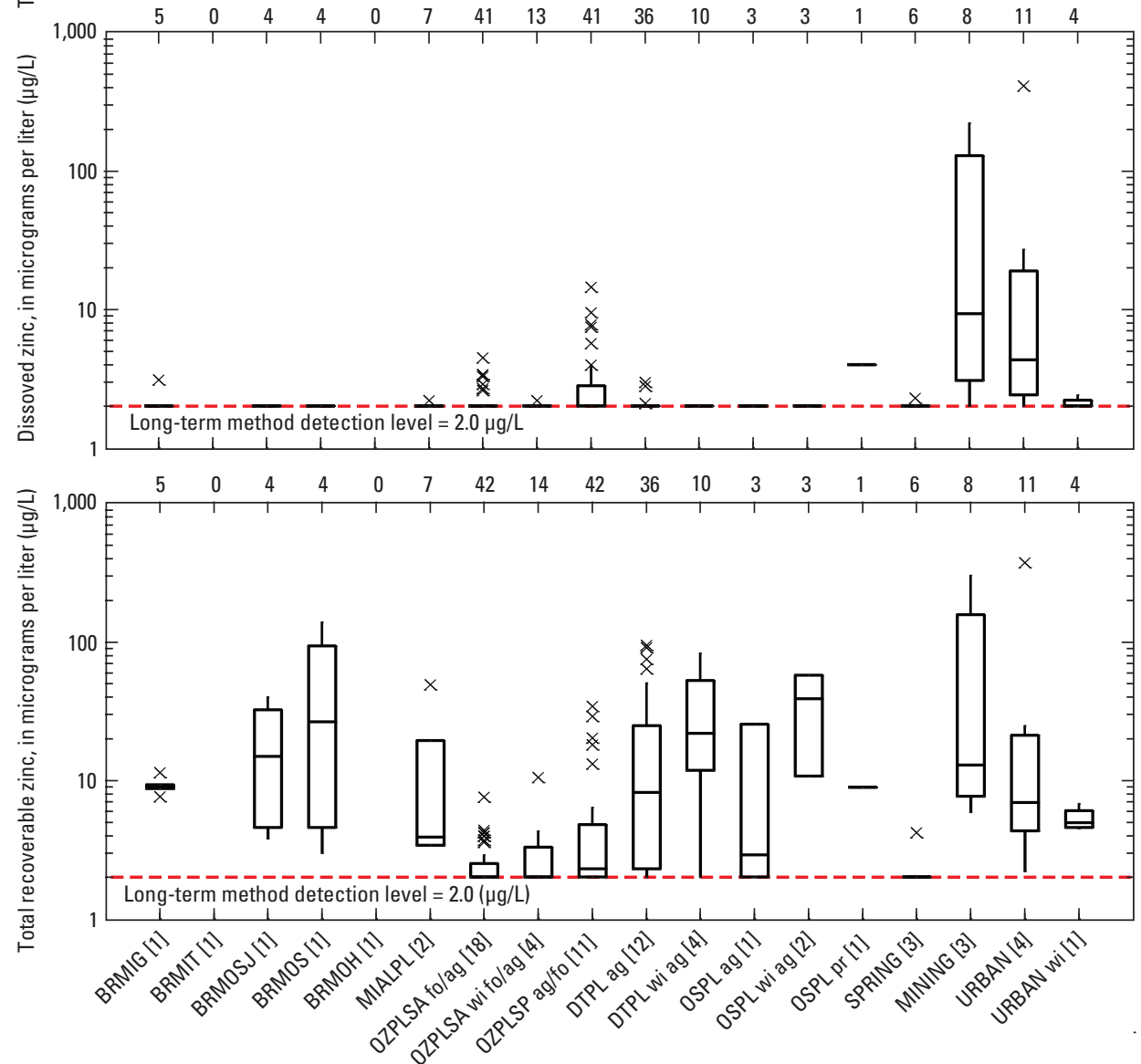

Station classification system (table 2) [number of stations in class]

Figure 8. Distribution of dissolved and total recoverable lead and zinc concentrations from 71 stations in Missouri, water year 2015. 


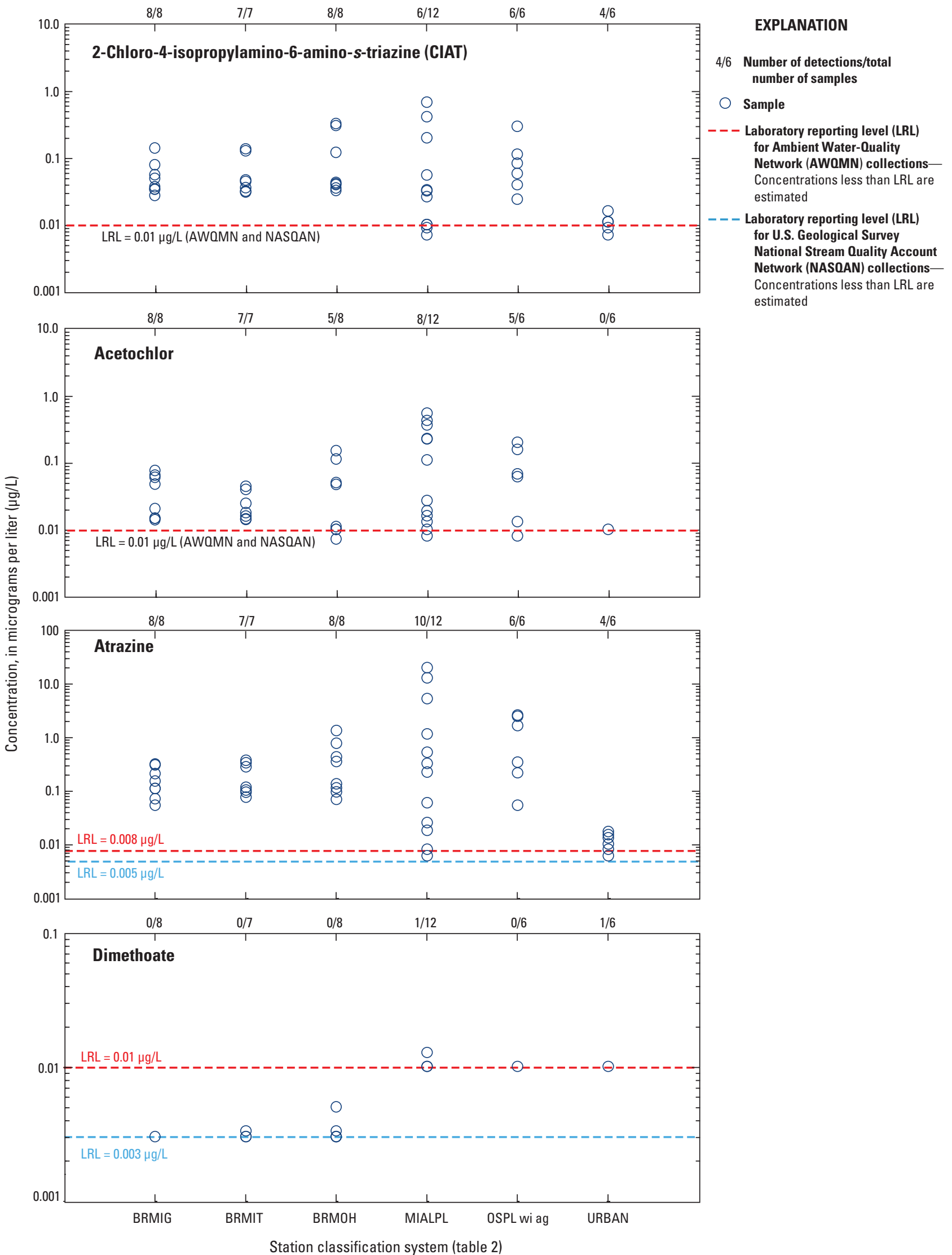

Figure 9. Detection of select pesticides from selected stations in Missouri, water year 2015. 


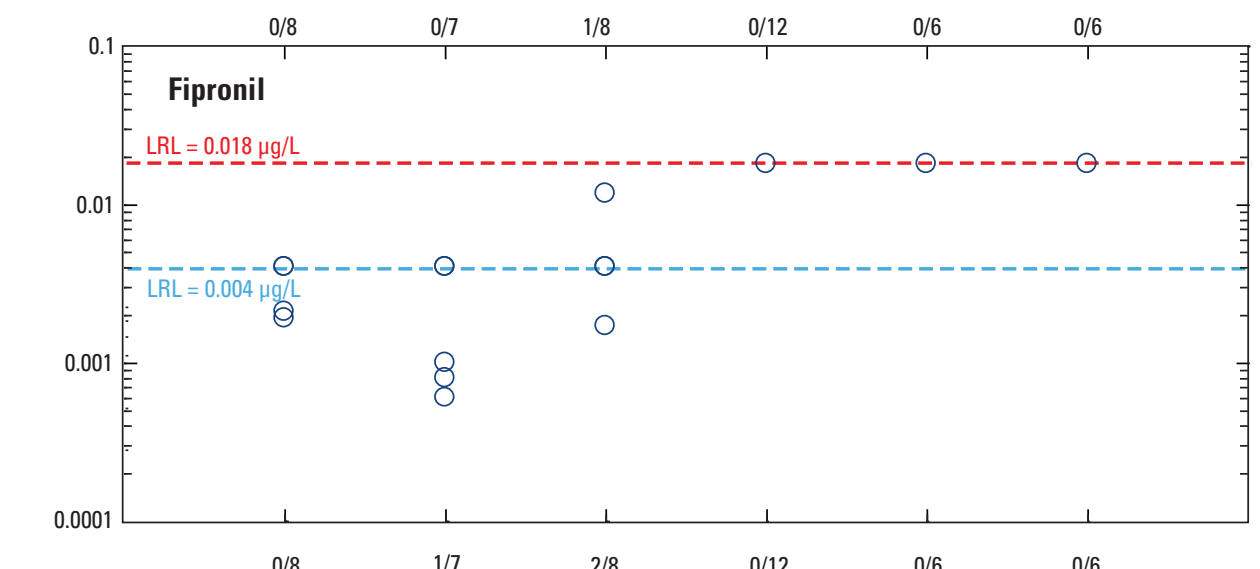

EXPLANATION

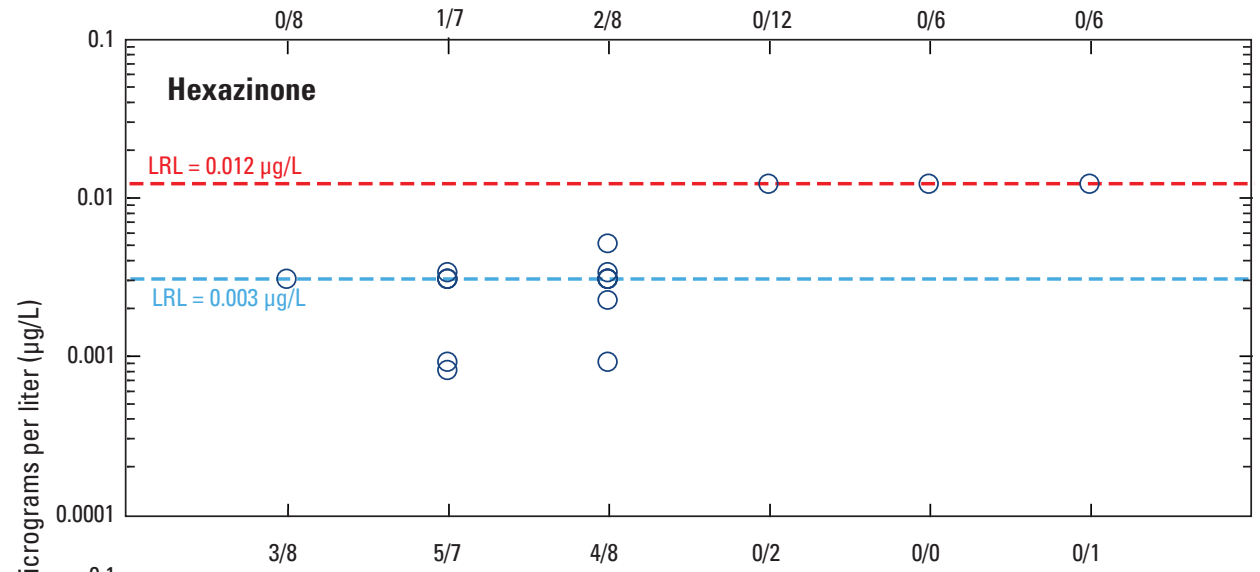

0/6 Number of detections/total number of samples

Sample

- - - Laboratory reporting level (LRL) for Ambient Water-Quality Network (AWOMN) collectionsConcentrations less than LRL are estimated

- - Laboratory reporting level (LRL)

for U.S. Geological Survey National Stream Quality Account Network (NASOAN) collectionsConcentrations less than LRL are estimated

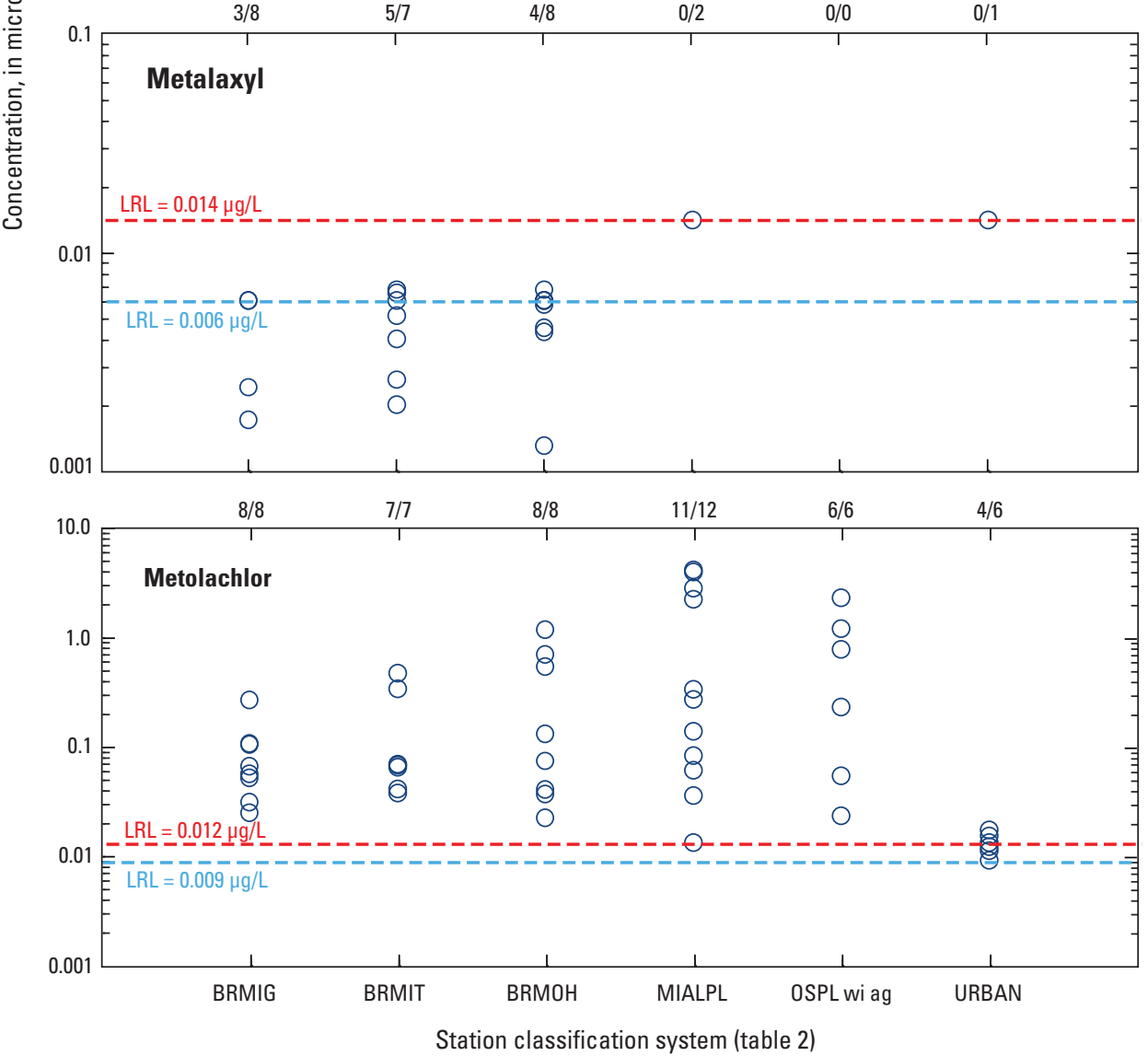

Figure 9. Detection of select pesticides from selected stations in Missouri, water year 2015._-Continued 


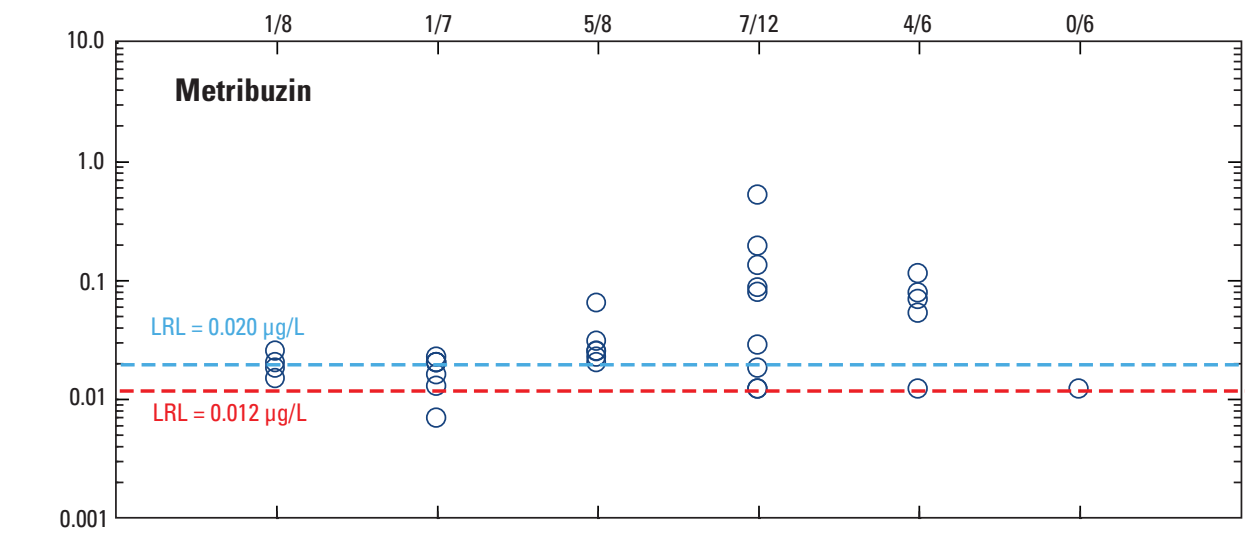

\section{EXPLANATION}

0/6 Number of detections/total number of samples

Sample

- - Laboratory reporting level (LRL) for Ambient Water-Quality Network (AWOMN) collectionsConcentrations less than LRL are estimated

- - - Laboratory reporting level (LRL)

for U.S. Geological Survey

National Stream Quality Account Network (NASOAN) collections-

Concentrations less than LRL are estimated
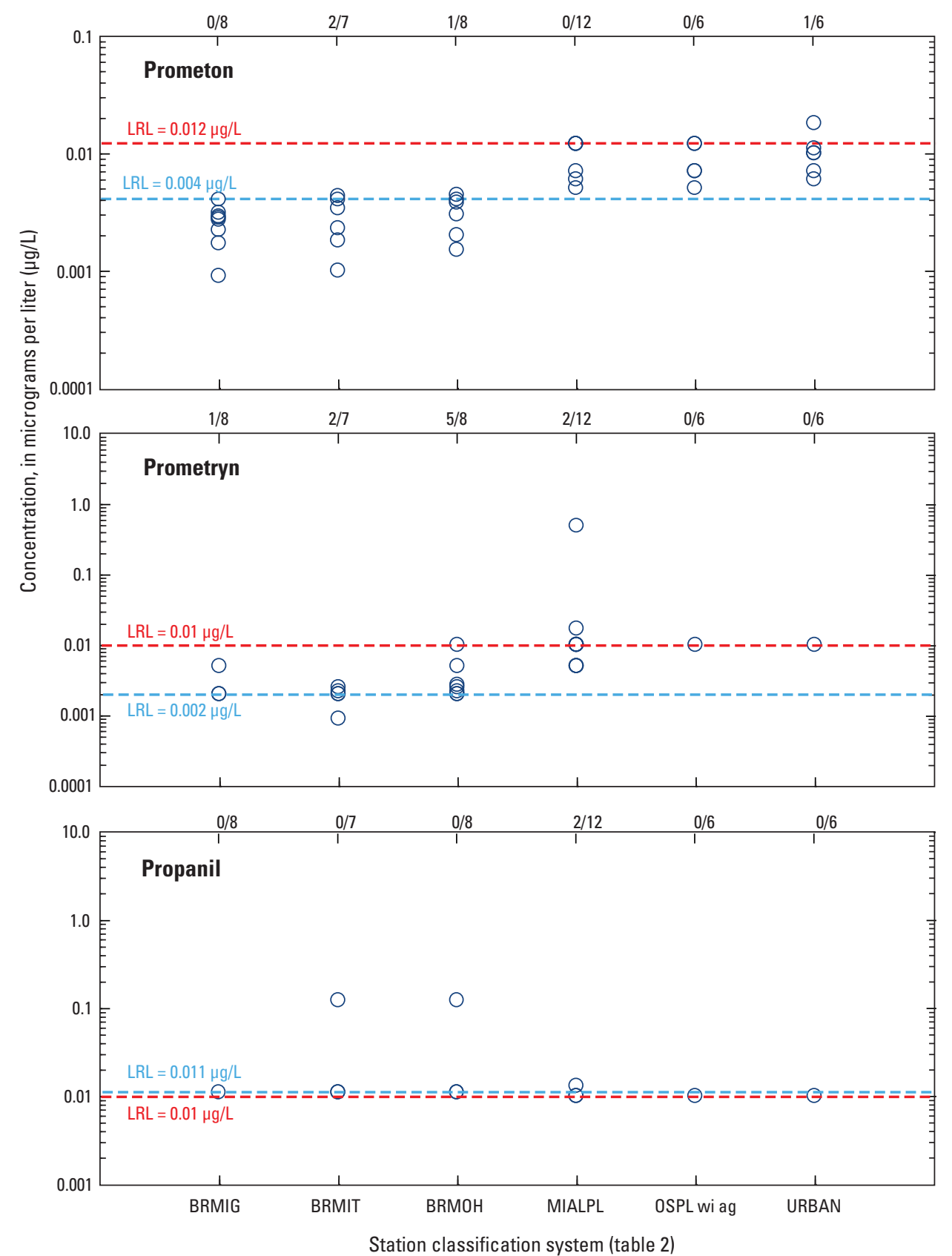

Figure 9. Detection of select pesticides from selected stations in Missouri, water year 2015. - Continued 

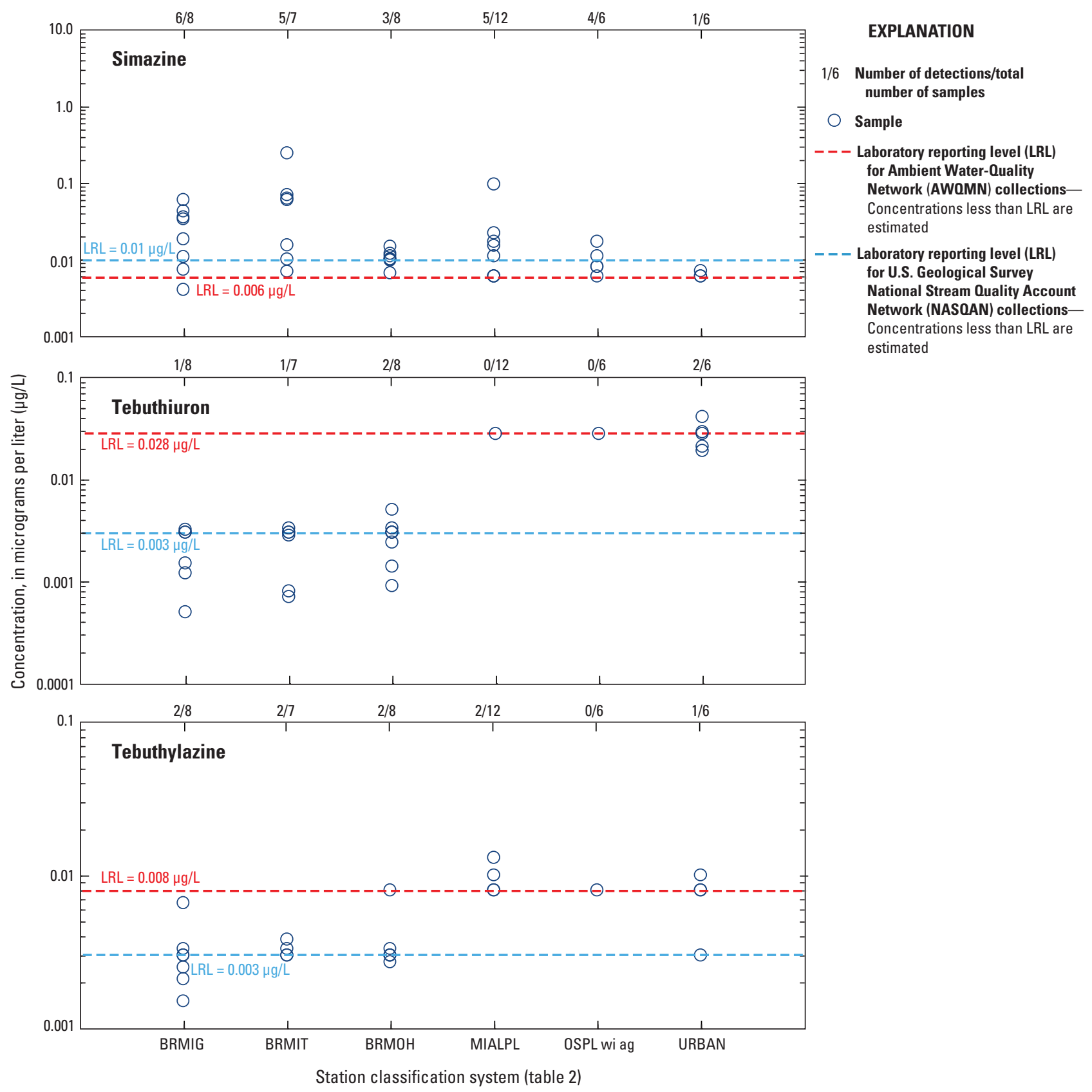

Figure 9. Detection of select pesticides from selected stations in Missouri, water year 2015. - Continued

\section{Summary}

The U.S. Geological Survey, in cooperation with the Missouri Department of Natural Resources, collects surface-water quality data pertaining to water resources in Missouri each water year (October 1 through September 30). These data, stored and maintained in the U.S. Geological Survey National Water Information System database, are collected as part of the Missouri Ambient Water-Quality Monitoring Network and constitute a source of reliable, impartial, and timely information for developing an enhanced understanding of the State's water resources. The U.S. Geological Survey, in cooperation with the U.S. Army Corps of Engineers, also routinely collects suspended-sediment concentration data and various particlesize distribution data on the Missouri and Mississippi Rivers. These data assist with sediment transport and navigable channel assessments along the larger rivers.

Surface-water quality data were collected at 74 stations in water year 2015-72 Ambient Water-Quality Monitoring Network stations and 2 U.S Geological Survey National Stream Quality Assessment Network stations. Data are summarized in this report for 71 of the stations including four stations with suspended-sediment data. Stations were classified into groups 
corresponding to the physiography of the State, primary land use, or unique station types. The annual summary of select constituents provides Missouri Department of Natural Resources with current information to assess the quality of surface water within the State and ensure the objectives of the Ambient Water Quality Network are being met. The data collected also provide support for the design, implementation, and evaluation of preventive and remediation programs.

The analyses presented in this report include the following constituents: DO, specific conductance, water temperature, suspended solids, suspended sediment, Escherichia coli bacteria, fecal coliform bacteria, dissolved nitrate plus nitrite as nitrogen, total phosphorus, and dissolved and total recoverable lead and zinc. Plots of the concentrations of these constituents are presented by the different station classes. In addition, pesticide data were analyzed from seven stations from six classes. A summary of hydrologic conditions in the State including peak streamflows, monthly mean streamflows, and 7-day low flows also is presented.

\section{References Cited}

Barr, M.N., 2010, Quality of surface water in Missouri, water year 2009: U.S. Geological Survey Open-File Report 2010-1233, 22 p., accessed July 2016 at http://pubs.usgs. gov/of/2010/1233/.

Barr, M.N., 2011, Quality of surface water in Missouri, water year 2010: U.S. Geological Survey Data Series 636, 21 p., accessed July 2016 at http://pubs.usgs.gov/ds/636/.

Barr, M.N., 2013, Quality of surface water in Missouri, water year 2011: U.S. Geological Survey Data Series 734, 22 p., accessed July 2016 at http://pubs.usgs.gov/ds/734/.

Barr, M.N., 2014, Quality of surface water in Missouri, water year 2012: U.S. Geological Survey Data Series 818, 24 p., accessed July 2016 at http://dx.doi.org/10.3133/ds818.

Barr, M.N., 2015, Quality of surface water in Missouri, water year 2014: U.S. Geological Survey Data Series 971, 22 p., accessed July 2016 at http://dx.doi.org/10.3133/ds971.

Barr, M.N., and Davis, J.V., 2010, Surface-water quality conditions and long-term trends at selected sites within the ambient water-quality monitoring network in Missouri, water years 1993-2008: U.S. Geological Survey Scientific Investigations Report 2010-5078, 42 p. [Also available at http://pubs.usgs.gov/sir/2010/5078/.]

Barr, M.N., and Schneider, R.E., 2014, Quality of surface water in Missouri, water year 2013: U.S. Geological Survey Data Series 886, 21 p., accessed August 2016 at http://pubs. usgs.gov/ds/0886/.
Childress, C.J.O., Foreman, W.T., Connor, B.F., and Maloney, T.J., 1999, New reporting procedures based on longterm method detection levels and some considerations for interpretations of water-quality data provided by the U.S. Geological Survey National Water Quality Laboratory: U.S. Geological Survey Open-File Report 99-193, 19 p. [Also available at http://water.usgs.gov/owq/OFR_99-193/index. html.]

Edwards, T.K., and Glysson, G.D., 1999, Field methods for measurement of fluvial sediment: U.S. Geological Survey Techniques of Water-Resources Investigations, book 3, chap. C2, accessed August 2016 at http://pubs.usgs.gov/ twri/twri3-c2/.

Fenneman, N.M., 1938, Physiography of eastern United States: New York, McGraw-Hill Book Co., Inc., 689 p.

Fishman, M.J., ed., 1993, Methods of analysis by the U.S. Geological Survey National Water Quality Laboratory_Determination of inorganic and organic constituents in water and fluvial sediments: U.S. Geological Survey Open-File Report 93-125, 217 p. [Also available at http://pubs.er.usgs.gov/publication/ofr93125.]

Garbarino, J.R., Kanagy, L.K., and Cree, M.E., 2006, Determination of elements in natural-water, biota, sediment and soil samples using collision/reaction cell inductively coupled plasma-mass spectrometry: U.S. Geological Survey Techniques and Methods, book 5, chap. B1, 88 p. [Also available at http://pubs.usgs.gov/tm/2006/tm5b1/.]

Guy, H.P., 1969, Laboratory theory and methods for sediment analysis: U.S. Geological Survey Techniques of WaterResources Investigations, book 5, chap. C1, accessed July 2016 at http://pubs.usgs.gov/twri/twri5c1/.

Helsel, D.R., and Hirsch, R.M., 2002, Statistical methods in water resources: U.S. Geological Survey Techniques of Water-Resources Investigations, book 4, chap. A3, accessed July 2016 at http://pubs.usgs.gov/twri/twri4a3/.

Missouri Department of Natural Resources, 2014a, Missouri integrated water quality report and section 303(d) list, 2014: Jefferson City, Mo., Missouri Department of Natural Resources, Water Protection Program, accessed August 2016 at http://dnr.mo.gov/env/wpp/waterquality/303d/303d. htm.

Missouri Department of Natural Resources, 2014b, Water quality, chap. 7 of Rules of Department of Natural Resources-Division 20-Clean Water Commission: Jefferson City, Mo., Missouri Department of Natural Resources, Clean Water Commission, 151 p., accessed August 2016 at http://s1.sos.mo.gov/cmsimages/adrules/csr/ current/10csr/10c20-7a.pdf. 
Myers, D.N., Stoeckel, D.M., Bushon, R.N., Francy, D.S., and Brady, A.M.G., 2014, Fecal indicator bacteria (ver. 2.1): U.S. Geological Survey Techniques of Water-Resources Investigations, book 9, chap. A7, sec. 7.1, accessed May 2016 at http://pubs.water.usgs.gov/twri9A/.

National Oceanic and Atmospheric Administration, 2016a, State of the climate-National overview-Annual 2015: National Oceanic and Atmospheric Administration, National Centers for Environmental Information, accessed May 2016 at http://www.ncdc.noaa.gov/sotc/national/201513.

National Oceanic Atmospheric Administration, 2016b, Climate at a glance-Missouri climate summary: National Oceanic Atmospheric Administration, National Climatic Data Center database, accessed May 2016 at http://www. ncdc.noaa.gov/cag/.

Otero-Benitez, William, and Davis, J.V., 2009a, Quality of surface water in Missouri, water year 2007: U.S. Geological Survey Open-File Report 2009-1096, 19 p., accessed May 2016 at http://pubs.usgs.gov/of/2009/1096/.

Otero-Benitez, William, and Davis, J.V., 2009b, Quality of surface water in Missouri, water year 2008; U.S. Geological Survey Open-File Report 2009-1214, 18 p., accessed May 2016 at http://pubs.usgs.gov/of/2009/1214/.

Patton, C.J., and Truitt, E.P., 1992, Methods of analysis by the U.S. Geological Survey National Water Quality Laboratory-Determination of total phosphorus by a Kjeldahl digestion method and an automated colorimetric finish that includes dialysis: U.S. Geological Survey Open-File Report 92-146, 39 p. [Also available at http://pubs.er.usgs.gov/publication/ofr92146.]

Patton, C.J., and Kryskalla, J.R., 2011, Colorimetric determination of nitrate plus nitrite in water by enzymatic reduction, automated discrete analyzer methods: U.S. Geological Survey Techniques and Methods, book 5, chap. B8, 48 p. [Also available at http://pubs.usgs.gov/tm/05b08/.]

Sandstrom, M.W., Stroppel, M.E., Foreman, W.T., and Schroeder, M.P., 2001, Methods of analysis by the U.S. Geological Survey National Water Quality LaboratoryDetermination of moderate-use pesticides and selected degradates in water by $\mathrm{C}-18$ solid-phase extraction and gas chromatography/mass spectrometry: U.S. Geological Survey Water-Resources Investigations Report 01-4098, 70 p. [Also available at http://nwql.usgs.gov/pubs/WRIR/ WRIR-01-4098.pdf.]

Sandstrom, M.W., and Wilde, F.D., 2014, Syringe-filter procedure for processing samples for analysis of organic compounds by DAI LC-MS/MS: U.S. Geological Survey Techniques of Water Resources Investigations, book 9, chap A5 sec. 2.2.B, accessed August 2016 at http://pubs.water. usgs.gov/twri9A5/.
U.S. Census Bureau, 2016, U.S. population estimates: U.S. Census Bureau, accessed May 2016 at http://www.census. gov/.

U.S. Environmental Protection Agency, 1997, Guidelines for preparation of the comprehensive state water quality assessments (305(b) reports) and electronic updates (1997): Washington, D.C., Office of Water, EPA-841-B97-002A, [variously paged], accessed May 2016 at http://www.epa. gov/owow/monitoring/guidelines.html.

U.S. Geological Survey, 1964-2005, Water resources dataMissouri: U.S. Geological Survey, [variously paged].

U.S. Geological Survey, 2006a, Collection of water samples (ver. 2.0): U.S. Geological Survey Techniques of WaterResources Investigations, book 9, chap. A4, accessed May 2016 at http://pubs.water.usgs.gov/twri9A4.

U.S. Geological Survey, 2006b-2010, Water resources data for the United States-Annual water-data report: U.S. Geological Survey, accessed May 2016 at http://wdr.water.usgs. gov/.

U.S. Geological Survey, variously dated, National field manual for the collection of water-quality data: U.S. Geological Survey Techniques of Water-Resources Investigations, book 9, chaps. A1-A9, accessed May 2016 at http://pubs.water. usgs.gov/twri9A.

Wilde, F.D., ed., variously dated, Field measurements: U.S. Geological Survey Techniques of Water-Resources Investigations, book 9, chap. A6, accessed May 2016 at http:// pubs.water.usgs.gov/twri9A6/.

Wilde, F.D., Radtke, D.B., Gibs, Jacob, and Iwatsubo, R.T., eds., 2004, with updates through 2009, Processing of water samples (ver. 2.2): U.S. Geological Survey Techniques of Water-Resources Investigations, book 9, chap. A5, accessed May 2016 at http://pubs.water.usgs.gov/twri9A5/.

Zaugg, S.D., Sandstrom, M.W., Smith, S.G., and Fehlberg, K.M., 1995, Methods of analysis by the U.S. Geological Survey National Water Quality Laboratory-Determination of pesticides in water by $\mathrm{C}-18$ solid-phase extraction and capillary-column gas chromatography/mass spectrometry with selected-ion monitoring: U.S. Geological Survey Open-File Report 95-181, 49 p. [Also available at http:// pubs.usgs.gov/of/1995/0181/report.pdf.] 
Publishing support provided by:

Rolla Publishing Service Center

For more information concerning this publication, contact: Director, USGS Missouri Water Science Center

1400 Independence Road

Rolla, MO 65401

(573) 308-3667

Or visit the Missouri Water Science Center Web site at: http://mo.water.usgs.gov/ 


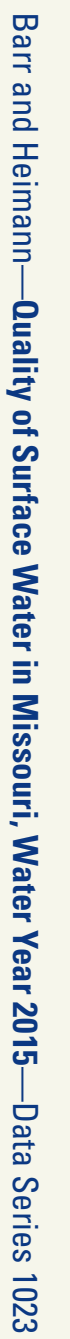

